\title{
Identifying the Compounds of the Metabolic Elicitors of Pseudomonas fluorescens N 21.4 Responsible for Their Ability to Induce Plant Resistance
}

\author{
Helena Martin-Rivilla ${ }^{1, * \mathbb{D}}$, F. Javier Gutierrez-Mañero ${ }^{1}$, Ana Gradillas ${ }^{2}$, \\ Miguel O. P. Navarro $^{3}\left(\mathbb{D}\right.$, Galdino Andrade ${ }^{3}(\mathbb{D})$ and José A. Lucas ${ }^{1}$ (D) \\ 1 Plant Physiology Pharmaceutical and Health Sciences Department, Faculty of Pharmacy, \\ Universidad San Pablo-CEU Universities, 28668 Madrid, Spain; jgutierrez.fcex@ceu.es (F.J.G.-M.); \\ alucgar@ceu.es (J.A.L.) \\ 2 Centre for Metabolomics and Bioanalyses, Faculty of Pharmacy, Universidad San Pablo-CEU Universities, \\ 28668 Madrid, Spain; gradini@ceu.es \\ 3 Laboratory of Microbial Ecology, Department of Microbiology, Londrina State University, \\ Londrina 86051-990, Brazil; micromiguel@gmail.com (M.O.P.N.); andradeg@uel.br (G.A.) \\ * Correspondence: hel.martin.ce@ceindo.ceu.es; Tel.: +34-913-72-47-85
}

Received: 11 July 2020; Accepted: 8 August 2020; Published: 12 August 2020

\begin{abstract}
In this work, the metabolic elicitors extracted from the beneficial rhizobacterium Pseudomonas fluorescens N 21.4 were sequentially fragmented by vacuum liquid chromatography to isolate, purify and identify the compounds responsible for the extraordinary capacities of this strain to induce systemic resistance and to elicit secondary defensive metabolism in diverse plant species. To check if the fractions sequentially obtained were able to increase the synthesis of isoflavones and if, therefore, they still maintained the eliciting capacity of the live strain, rapid and controlled experiments were done with soybean seeds. The optimal action concentration of the fractions was established and all of them elicited isoflavone secondary metabolism - the fractions that had been extracted with n-hexane being more effective. The purest fraction was the one with the highest eliciting capacity and was also tested in Arabidopsis thaliana seedlings to induce systemic resistance against the pathogen Pseudomonas syringae pv. tomato DC 3000. This fraction was then analyzed by UHPLC/ESI-QTOF-MS, and an alkaloid, two amino lipids, three arylalkylamines and a terpenoid were tentatively identified. These identified compounds could be part of commercial plant inoculants of biological and sustainable origin to be applied in crops, due to their potential to enhance the plant immune response and since many of them have putative antibiotic and/or antifungal potential.
\end{abstract}

Keywords: Pseudomonas fluorescens N 21.4; metabolic elicitors; isoflavone elicitation; induced systemic resistance; sphingolipids; terpenoids

\section{Introduction}

Protecting crops against diseases caused by pathogens in agricultural systems has always been a constant challenge when trying to maximize crop yields, minimize economic losses and ensure quality food worldwide [1]. As 2020 has been declared International Year of Plant Health by the FAO (Food and Agriculture Organization of the United Nations), the current challenge is to find effective, ecofriendly and at the same time, low-cost agriculture control methods that guarantee the sustainability of crop production while eliminating negative impact on the environment.

It has been widely demonstrated that biological agents, such as beneficial microorganisms, are able to enhance plants' immune systems, inducing systemic resistance (ISR) and/or systemic acquired resistance (SAR) [2-4]. This phenomenon of enhancing a plant's immune system is called 
elicitation, and it supposes that cells exposed to external factors activate defense mechanisms by triggering and regulating some biochemical and molecular responses, increasing the synthesis of specific molecules with a protective role [5]. After elicitor perception, signals are transported throughout the plant, triggering local and systemic responses [6] and leading to the generation of reactive oxygen species (ROS), phytoalexin biosynthesis, increased synthesis of antioxidant secondary metabolites, reinforcement of plant cell wall, deposition of callose, synthesis of defense enzymes, accumulation of pathogenesis-related proteins [7], etc.

Originally, the term elicitor referred to molecules capable of inducing the production of phytoalexins, but nowadays it is commonly used for compounds that stimulate any defensive line [8-10]. Natural elicitor molecules derived from microorganisms can induce similar defense responses in plants to those responses induced by the alive microorganisms [11]. Different types of natural elicitor molecules have been characterized, including structural molecules, such as carbohydrate polymers, lipids, and bacterial flagellin [12], and metabolic elicitors, released to the medium, such as antibiotics and secondary metabolites $[13,14]$.

Currently, a wide range of metabolic elicitors produced by fungi and beneficial rhizobacteria have been found to induce in plants the synthesis of protective compounds-such as phytoalexins, defensins, phenolic acids, and flavonoids-that directly suppress pathogens [15]. They can reduce plant diseases through elicitation of physical and chemical processes linked to systemic plant defense mechanisms [16]. This is why plant inoculants made of beneficial rhizobacteria and/or their metabolic elicitors have been seen as feasible and effective alternatives to chemical phytosanitaries to counteract the attack of pathogens and also to face to diverse biotic and abiotic stresses [17,18]. However, using elicitor molecules instead of living bacteria is a way to reduce the cost and to simplify the production and subsequent management of plant inoculants. Products made of partially purified or purified compounds derived from bacterial metabolism [19] are cheap to produce; easy to manage; respectful with the environment; not harmful or toxic to human health or to other organisms, as their targets are directly the plants; and do not cause biosecurity problems as bacteria could cause [20]. Furthermore, they can be easily applied by spraying [21] and they do not require special preservation conditions like live microorganisms because they are stable during long periods of exposure to light and/or high temperatures [22] and they do not lose viability during prolonged storage.

Among beneficial microorganisms, the genus Pseudomonas spp. and Bacillus spp. are the most studied genera concerning everything related to plant-pathogen-beneficial microorganism interactions and the improvement of plant immune system, because they are very abundant in the soil and because of their role in the suppression of pathogens [23]. Literature has shown that Pseudomonas spp. have extensive metabolic capabilities and adaptable biochemistry through their production of structurally varied bioactive molecules [24]. Furthermore, it is largely known that Pseudomonas spp. are some of the most important microorganisms able to produce compounds with antibiotic or eliciting activity triggering SAR [25] or ISR [3].

The potential of Pseudomonas spp. to suppress plant pathogens has been demonstrated in many plant species and around the world [26]. They can be used as efficient and not-risky biocontrol agents to use in agriculture because they do not show pathogenic, allergenic or harmful risks to people or animals [27]. Secondary metabolites isolated from Pseudomonas spp. that could be an alternative to the use of chemical compounds in the control of plant disease include phenazines, pyrrolnitrin-type antibiotics, betalactones, pyo compounds, indol derivatives, peptides, glycolipids, lipids, aromatic organic compounds and aliphatic compounds, among others [24,28].

More specifically and within Pseudomonas spp. genus, the specie Pseudomonas fluorescens is a Gram-negative soil bacterium that has been widely studied in relation to its capacity to suppress other pathogenic microorganisms by producing siderophores, antibiotics and antifungal and antiparasitic compounds and to induce systemic resistance in plants through a vast variety of secondary metabolites with eliciting capacity [28-31]. For all of this, certain strains have already been developed as commercial products for management of plant illnesses in agricultural settings [22]. 
The $P$. fluorescens strain N 21.4 was specifically used in the present work because its capacity to induce systemic resistance in different plant species, such as Arabidopsis thaliana [18,32], Solanum lycopersicum [33], Hypericum sp. [34], Papaver sp. [35] and blackberry (Rubus cv. Loch Ness) has been largely demonstrated [36-39]. Its metabolic elicitors have also been demonstrated to induce systemic resistance in A. thaliana [18] and to elicit flavonoid metabolism in the leaves and in the fruits of cultivars of blackberry $[38,39]$.

For all the above, the objective of the present study was to isolate, purify, test and identify the compound or set of elicitor compounds of P. fluorescens $\mathrm{N} 21.4$, obtained from sequential fractionations of its metabolic elicitors by vacuum liquid chromatography (VLC), responsible for plant elicitation. To corroborate fractions' capacities to elicit secondary metabolism, some experiments under controlled conditions were performed in soybean seeds to enhance isoflavone synthesis and in A. thaliana to induce systemic resistance. A final analysis to obtain the profile of main compounds present in the purest fraction of the metabolic elicitors was made by ultra-high performance liquid chromatography (UHPL), with an electrospray ionization source (ESI) and a quadrupole time-of-flight mass spectrometry analyzer (QTOF-MS). Eight compounds were tentatively identified and classified into different families: alkaloids, amino lipids, terpenoids and arylalkylamines.

\section{Material and Methods}

Sequential extraction, fragmentation and purification of the metabolic elicitors of $P$. fluorescens $\mathrm{N}$ 21.4 were carried out (Figure 1 and Table 1). Firstly, a liquid-liquid phase separation was made [40], followed by two sequential VLCs. All the sequentially fragmented fractions were inoculated in soybean seeds to analyze their capacity to elicit isoflavone secondary metabolism pathway. Final isolation and purification were performed. The resulting fraction of the entire process of fragmentation and purification was tested in an ISR experiment in A. thaliana seedlings. Finally, this fraction, the purest one, was analyzed by UHPLC/ESI-QTOF-MS to characterize its composition.

\subsection{Bacterial Strain}

The bacterial strain used in this study was P. fluorescens N 21.4 (Spanish Type Culture Collection accession number CECT 7620), a Gram-negative bacilli isolated from the rhizosphere of Nicotiana glauca Graham [33]. The bacterial strain was stored at $-80{ }^{\circ} \mathrm{C}$ in nutrient broth (CONDA) with $20 \%$ glycerol.

\subsection{Metabolic Elicitor Extraction and Control Obtaining}

The bacterial strain, stored at $-80{ }^{\circ} \mathrm{C}$ in nutrient broth with $20 \%$ glycerol, was streaked onto nutrient agar (peptone $3 \mathrm{~g} \cdot \mathrm{L}^{-1}$, beef extract $5 \mathrm{~g} \cdot \mathrm{L}^{-1}$ and agar $15 \mathrm{~g} \cdot \mathrm{L}^{-1} \mathrm{pH}$ 7) plates and cultivated for $24 \mathrm{~h}$ at $28^{\circ} \mathrm{C}$. After $24 \mathrm{~h}$ of growth, bacterial cells were scraped off the plates into $10 \mathrm{~L}$ of sterile nutrient broth (peptone $3 \mathrm{~g} \cdot \mathrm{L}^{-1}$ and beef extract $5 \mathrm{~g} \cdot \mathrm{L}^{-1} \mathrm{pH}$ ) and incubated on a rotatory shaker at $28^{\circ} \mathrm{C}$ and $180 \mathrm{rpm}$ for $24 \mathrm{~h}$.

Metabolic elicitors (released into the medium) were obtained by centrifuging the $10 \mathrm{~L}$ of N 21.4 culture at $2890 \times g$ during $20 \mathrm{~min}$ at $4{ }^{\circ} \mathrm{C}$. Cells were discarded and the remaining supernatant was evaporated in a stove at $60^{\circ} \mathrm{C}$ until obtaining $1 \mathrm{~L}$. This concentrated supernatant was filtrated through a $0.2 \mu \mathrm{m}$ nitrocellulose filter and extracted twice with a double volume of hexane $(v / v)$. The extract was evaporated to dryness in a Buchi R-215 rotary evaporator at $50{ }^{\circ} \mathrm{C}$ [40]. The dry extract was weight (250 mg) and stored at $4{ }^{\circ} \mathrm{C}$ protected from light and humidity.

To obtain the control 1, the same procedure was followed as for extracting the metabolic elicitors from the bacterium, but while carrying out the entire process exclusively with the nutrient medium (peptone $3 \mathrm{~g} \cdot \mathrm{L}^{-1}$ and beef extract $5 \mathrm{~g} \cdot \mathrm{L}^{-1} \mathrm{pH} 7$ ), in the absence of bacterium. 


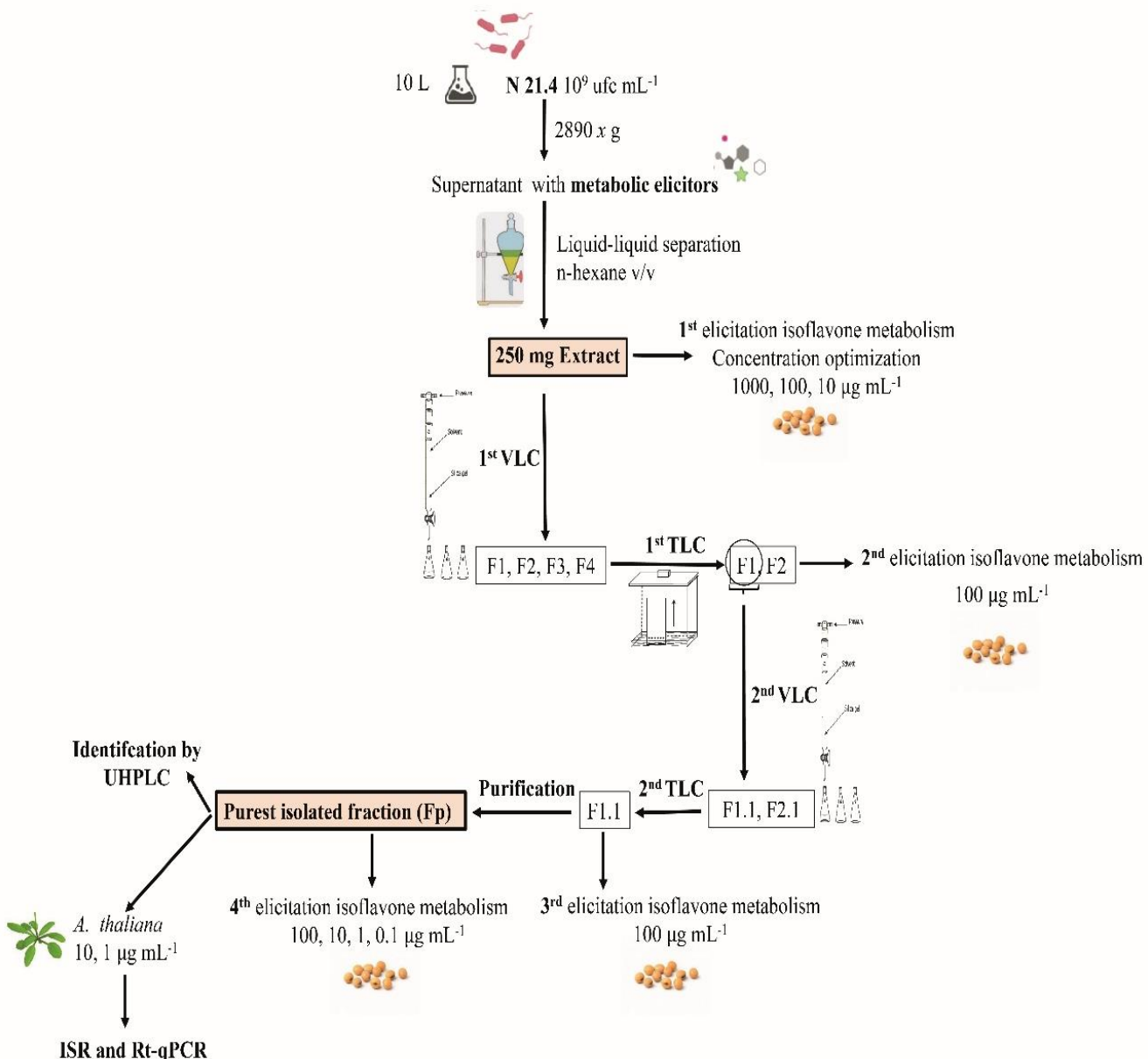

Figure 1. Representative scheme of the sequential extraction, fractionation and purification of the metabolic elicitors of P. fluorescens N 21.4. Shown are the growth of the bacterium in nutrient broth, the liquid-liquid phase separation with $n$-hexane, the process of fractionation and purification by two sequential vacuum liquid cromatographies, the four elicitation experiments of isoflavone metabolism, the ISR experiment in $A$. thaliana and the final compound identification by UHPLC.

Table 1. Experimental design and treatments used.

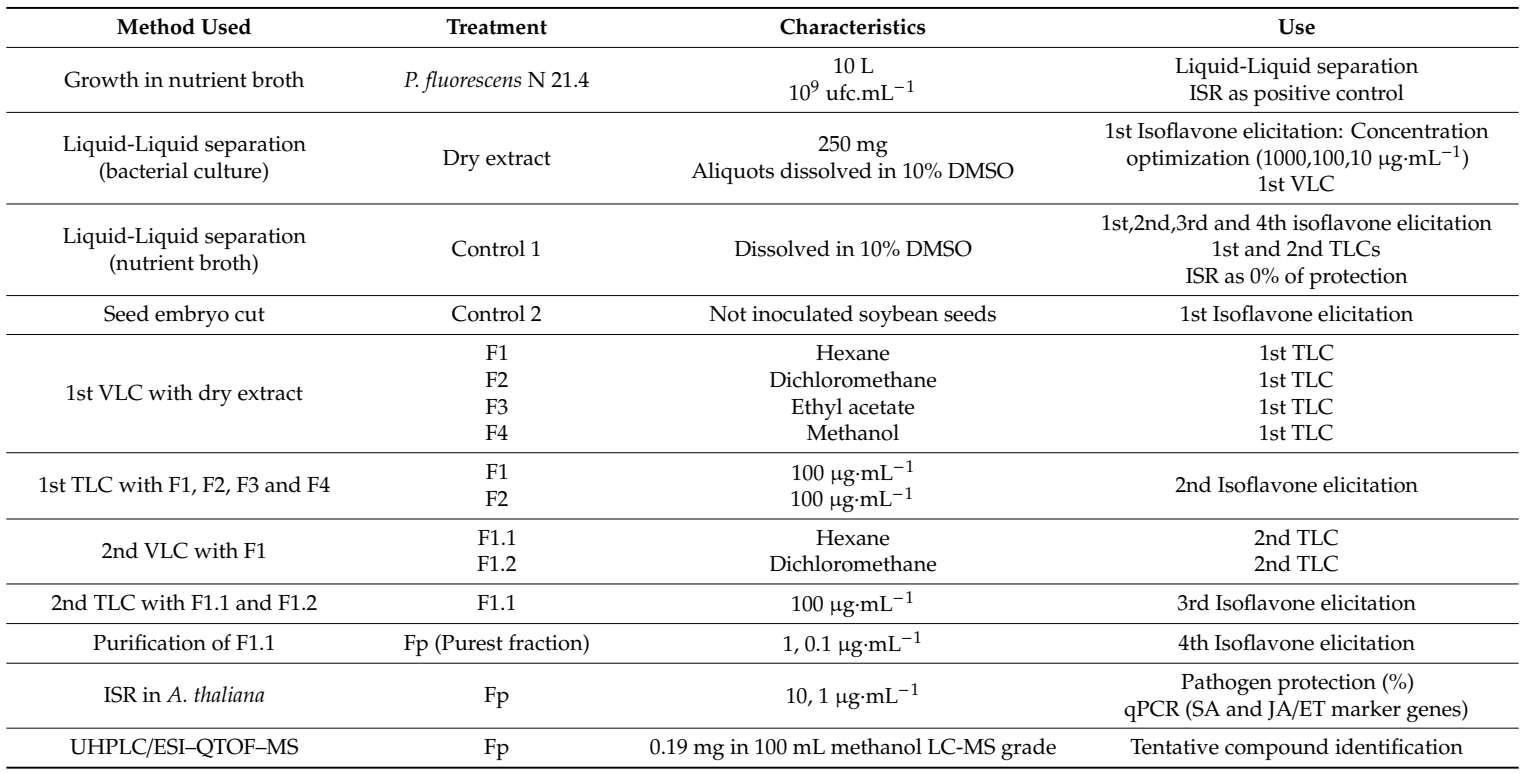




\subsection{Elicitation of Isoflavone Metabolism in the Soybean}

To test the capacity of the sequentially obtained fractions to elicit isoflavone secondary metabolism, rapid induction tests were carried out in soybean seeds (BS-2606 Embrapa). Seeds were superficially disinfected with a 70\% ethanol bath for $1 \mathrm{~min}, 5 \%$ sodium hypochlorite for 6 min and 5 washes with sterile distilled water. After that, seeds were kept imbibing in sterile distilled water for $4 \mathrm{~h}$, in darkness and at room temperature. After imbibition, 90 seeds per treatment and 90 seeds for each control (control 1 and 2), were distributed in 3 replicates of 30 seeds each and put to germinate in sterile Petri dishes with 1\% European bacteriological agar. A small longitudinal cut was made in the seeds embryo without compromising their viability.

For the first isoflavone elicitation experiment, three dilutions of concentration $1000,100 \mathrm{and} 10 \mu \mathrm{g} \cdot \mathrm{mL}^{-1}$ diluted in 10\% DMSO were prepared from the separated aliquot of the dry extract obtained by liquid-liquid separation, and $10 \mu \mathrm{L}$ of each dilution was inoculated into the cut of the seeds embryo. For the second isoflavone elicitation experiment, $10 \mu \mathrm{L}$ of fractions F1 and F2 at $100 \mu \mathrm{g} \cdot \mathrm{mL}^{-1}$, obtained from the first VLC, was inoculated. For the third isoflavone elicitation experiment, $10 \mu \mathrm{L}$ of F1.1 at $100 \mu \mathrm{g} \cdot \mathrm{mL}^{-1}$, obtained from the second VLC, was inoculated. For the fourth isoflavone elicitation experiment, $10 \mu \mathrm{L}$ of Fp at concentrations $100,10,1$ and $0.1 \mu \mathrm{g} \cdot \mathrm{mL}^{-1}$ was inoculated. This entire procedure was carried out under sterile conditions. Once the treatments were applied, the plates were kept in darkness for 3 days in a SANYO MLR $350 \mathrm{H}$ camera at $27^{\circ} \mathrm{C}$.

The extraction and analysis of isoflavones was performed according to Wang et al. [41] and Lozovaya et al. [42] with some modifications. Seeds were powdered with liquid nitrogen, mixed with $100 \mathrm{~mL}$ of $80 \%$ HPLC-methods methanol and maintained on an orbital shaker at $145 \mathrm{rpm}$ for $15 \mathrm{~h}$ at $40^{\circ} \mathrm{C}$. Samples were then centrifuged at $2890 \times g$ for $20 \mathrm{~min}$ at $20^{\circ} \mathrm{C}$. The obtained supernatant was filtered through a $0.2 \mu \mathrm{m}$ nitrocellulose membrane, and the methanolic extract was used for analysis by HPLC.

The identification and quantification of isoflavone was carried out on a chromatograph Agilent Technologies 1260 Infinity HPLC system. Chromatography conditions were: UV detection: $262 \mathrm{~nm}$, ZORBAZ 300SB-C18 column $(4.6 \mu \mathrm{m} \times 250 \mathrm{~mm} \times 5 \mu \mathrm{m})$, Gecko $200030,80{ }^{\circ} \mathrm{C}$ thermostat that kept the column at $30{ }^{\circ} \mathrm{C}$. The mobile phase consisted of water with $0.1 \%$ acetic acid (solvent A), and acetonitrile with $0.1 \%$ acetic acid (solvent B), with the following gradient: from $15 \%$ to $45 \%$ of $\mathrm{B}$ during $40 \mathrm{~min}$, rising until 100\% B during $1 \mathrm{~min}$ and remaining this composition for 9 min, after which it dropped to initial conditions (15\% B) for $1 \mathrm{~min}$ and held for $9 \mathrm{~min}$ to equilibrate the column. The flow was $1.5 \mathrm{~mL} \cdot \mathrm{min}^{-1}$ and the sample injection volume was $10 \mu \mathrm{L}$.

The quantification of the isoflavones $\left(\mu \mathrm{g} \cdot \mathrm{mL}^{-1}\right)$ was performed by interpolation of the relative area given by the detector on a calibration curve built for each isoflavone $\left(R^{2}>0.99\right)$. The calibration curves were built with the isoflavones (LC Laboratories): daidzin, genistin and malonyl genistin.

\subsection{Vacuum Liquid Chromatography (VLC)}

The two VLCs performed were carried out in a glass column $(20 \mathrm{~mm}$ diameter $\times 350 \mathrm{~mm} \mathrm{H})$ filled with $30 \mathrm{~g}$ of silica gel $60(0.063-0.200 \mathrm{~mm}$, Merck) coupled to a vacuum pump with $51 \mathrm{kPa}$. The starting extract for fractionation was crushed and mixed with silica gel 60 until obtaining a fine powder, which was placed on the top of the silica column and fractionated passing through the column the following mobile phases (from lower to higher polarity): hexane, dichloromethane, ethyl acetate and methanol, for the first VLC, and hexane and dichloromethane for the second VLC. Each organic solvents (400 mL) was passed through the column and concentrated in a rotary evaporator under vacuum at $50{ }^{\circ} \mathrm{C}$.

\subsection{Thin Layer Chromatography (TLC)}

Two thin layer chromatographies, using TLC plates of silica gel on aluminum support 60 F254 (Merk), were performed to qualitatively assess the components present in the control 1 and in 
the fractions obtained from the first VLC (F1, F3, F3 and F4) and in the fractions obtained from the second VLC (F1.1 and F1.2).

The mobile phase used was a mixture of chloroform/dichloromethane/ethyl acetate/methanol $(v / v / v / v)$. Ultraviolet light $(254 \mathrm{~nm}$ and $366 \mathrm{~nm})$ was used for revealing the TLC plates.

\subsection{Purification of F1.1}

F1.1 fraction, the most fractionated one, was dissolved in $1 \mathrm{~mL}$ of chloroform and put on a TLC plate, which was imbibed in a dichloromethane mobile phase. The band that appeared at the top of the plate (common to those bands that had appeared in the first and second TLCs) was removed by scraping the silica gel from the TLC aluminum plate. Scraped silica was mixed with $1 \mathrm{~mL}$ of $80 \%$ methanol for HPLC methods and centrifuged for $10 \mathrm{~min}$ at $6500 \times \mathrm{g}$ at room temperature. Precipitated silica was discarded and supernatant (containing the elicitor pure compound/s) was evaporated. The isolated and pure fraction $(\mathrm{Fp})(0.39 \mathrm{mg})$ was tested in soybean seeds and stored protected from light and humidity to later perform another experiment for checking its capacity to induce systemic resistance in A. thaliana.

\subsection{ISR Experiment}

An aliquot of the purest fraction (Fp) was dissolved in DMSO $10 \%$ at concentrations 10 and $1 \mu \mathrm{g} \cdot \mathrm{mL}^{-1}$ and used for an ISR experiment in A. thaliana. The ISR experiment was carried out as follows:

A. thaliana wild type Columbia ecotype 0 seeds (provided by the Nottingham Arabidopsis Stock Centre (NASC)) were germinated in quartz sand and two-week-old seedlings were then individually transplanted to $100 \mathrm{~mL}$ pots filled with peat/sand mixture (12/5) (60 g per pot). Forty-eight plants per treatment were used; plants were arranged in three replicates, with sixteen repetitions each. Plants were watered with $5 \mathrm{~mL}$ of tap water once a week and with $5 \mathrm{~mL}$ of half-strength Hoagland solution per plant once a week. Plants were inoculated by soil drench with $50 \mu \mathrm{L}$ of each treatment: Fp diluted in $10 \%$ DMSO at a concentration of $10 \mu \mathrm{g} \cdot \mathrm{mL}^{-1}$ and at $1 \mu \mathrm{g} \cdot \mathrm{mL}^{-1}$, in the first and second weeks after transplant. Control plants were-mock inoculated by soil drench with $50 \mu \mathrm{L}$ of control 1 . Another positive control was added, in which thirty-six plants (three replicates of 12 plants each) were inoculated by soil drench, in the first and second weeks after transplant, with $1 \mathrm{~mL}$ of a $10^{9}$ ucf.mL ${ }^{-1}$ P. fluorescens $\mathrm{N} 21.4$ suspension. Four days after the second inoculation, plants were pathogen challenged with the pathogen Pseudomonas syringae pv. tomato DC3000. One day before pathogen challenge, plants were maintained with $99 \%$ relative humidity to ensure stomata opening in order to allow disease progress. P. syringae pv. tomato DC3000 grown for $24 \mathrm{~h}$ was centrifuged $(10 \mathrm{~min}$ at $2890 \times \mathrm{g})$ and cells were suspended in $10 \mathrm{mM} \mathrm{MgSO}_{4}$ to achieve $10^{8} \mathrm{cfu} \cdot \mathrm{mL}^{-1}$. Inoculation was done by spraying the entirety of each plant with $250 \mathrm{~mL}$. Plants were incubated in a culture chamber (Sanyo MLR-350H) with an $8 \mathrm{~h}$ light $\left(350 \mu \mathrm{E} \mathrm{s}^{-1} \mathrm{~m}^{-2}\right.$ at $\left.24^{\circ} \mathrm{C}\right)$ and $16 \mathrm{~h}$ dark period $\left(20^{\circ} \mathrm{C}\right)$ at $70 \%$ relative humidity. All the leaves of twelve plants (four per replicate) of each treatment and of control 1 were harvested at 6,12 and $24 \mathrm{~h}$ after pathogen challenge (hapc), powdered in liquid nitrogen and stored at $-80^{\circ} \mathrm{C}$. These plant samples were used for gene expression analysis by qPCR. The 36 remaining plants (12 per replicate) of each treatment and of control 1, and the 36 plants of positive control, were used to record disease severity $72 \mathrm{~h}$ after pathogen inoculation as the number of leaves with disease symptoms relative to the total number of leaves. Results were relativized using the disease severity of leaves inoculated with the control 1 extract as $0 \%$ protection.

\subsection{RT-qPCR Experiment}

Total RNA was isolated from each replicate with PureLink RNA Micro Kit (Invitrogen, Waltham, MA, USA), DNAase treatment included. RNA purity was confirmed using NanodropTM. A retrotranscription followed by RT-qPCR was performed. 
The retrotranscription was performed using iScript tm cDNA Synthesis Kit (Bio-Rad, Hercules, CA, USA). All retrotranscriptions were carried out using a GeneAmp PCR System 2700 (Applied Biosystems): $5 \mathrm{~min} 25^{\circ} \mathrm{C}, 30 \mathrm{~min} 42^{\circ} \mathrm{C}, 5 \mathrm{~min} 85^{\circ} \mathrm{C}$, and hold at $4{ }^{\circ} \mathrm{C}$. Amplification was carried out with a MiniOpticon Real Time PCR System (Bio-Rad): $3 \mathrm{~min}$ at $95^{\circ} \mathrm{C}$ and then 39 cycles consisting of $15 \mathrm{~s}$ at $95{ }^{\circ} \mathrm{C}, 30 \mathrm{~s}$ at $55^{\circ} \mathrm{C}$ and $30 \mathrm{~s}$ at $72{ }^{\circ} \mathrm{C}$, followed by melting curve to check results. To describe the expression obtained in the analysis, cycle threshold $(\mathrm{Ct})$ was used. Standard curves were calculated for each gene, and the efficiency values ranged between 90 and $110 \%$. Results for gene expression were expressed as differential expression by the $2^{-\Delta \Delta C t}$ method. Sand gene (AT2G28390) was used as reference gen [43]. Gene primers used are shown in Table 2.

Table 2. Forward and reverse primers used in qPCR analysis.

\begin{tabular}{ccc}
\hline & Forward Primer & Reverse Primer \\
\hline AtNPR1 & $5^{\prime}$-TATTGTCAARTCTRATGTAGAT & 5'-TATTGTCAARTCTRATGTAGAT \\
AtPR1 & 5'-AGTTGTTTGGAGAAAGTCAG & 5'-GTTCACATAATTCCCACGA \\
AtICS & 5'-GCAAGAATCATGTTCCTACC & 5'AATTATCCTGCTGTTACGAG \\
AtPDF1 & $5^{\prime}$-TTGTTCTCTTTGCTGCTTTCGA & 5'-TTGGCTTCTCGCACAACTTCT \\
AtLOX2 & $5^{\prime}$-ACTTGCTCGTCCGGTAATTGG & 5'-GTACGGCCTTGCCTGTGAATG \\
AtPR3 & 5'-AAATCAACCTAGCAGGCCACT & 5'-GAGGGAGAGGAACACCTTGACT \\
Sand & 5'-CTGTCTTCTCATCTCTTGTC & 5'-TCTTGCAATATGGTTCCTG \\
\hline
\end{tabular}

2.9. Tentative Identification and Characterization by UHPLC/ESI-QTOF-MS

\subsubsection{Sample Preparation}

The remaining content $(0.19 \mathrm{mg})$ of the purest fraction (Fp) was dissolved in $100 \mu \mathrm{L}$ of methanol, LC-MS grade, and vortex mixed for $3 \mathrm{~min}$. The mixture was then centrifuged at $10,000 \times g$ for $5 \mathrm{~min}$ and supernatant was collected for direct analysis.

\subsubsection{UHPLC-MS Analysis}

Samples were analyzed on a 1290 Infinity series UHPLC system coupled through an electrospray ionization source (ESI) with Jet Stream technology to a 6545 iFunnel QTOF/MS system (Agilent Technologies, Waldbronn, Germany). For the separation, a volume of $2 \mu \mathrm{L}$ was injected in a reversed-phase column (Zorbax Eclipse XDB-C18 $4.6 \times 50 \mathrm{~mm}, 1.8 \mu \mathrm{m}$, Agilent Technologies) at $40{ }^{\circ} \mathrm{C}$. The flow rate was $0.5 \mathrm{~mL} \cdot \mathrm{min}^{-1}$ with a mobile phase consisted of solvent $\mathrm{A}: 0.1 \%$ formic acid, and solvent B: methanol. Gradient elution consisted of $2 \%$ B (0-6 min), 2-50 \% B (6-10 min), $50-95 \%$ B (11-18 $\mathrm{min}), 95 \%$ B for $2 \mathrm{~min}$ (18-20 min), and returned to starting conditions $2 \% \mathrm{~B}$ in one minute (20-21 $\mathrm{min}$ ) to finally keep the re-equilibration with a total analysis time of $25 \mathrm{~min}$. Detector was operated in full scan mode $\left(\mathrm{m} / \mathrm{z} 50\right.$ to 2000), at a scan rate of $1 \mathrm{scan} \cdot \mathrm{s}^{-1}$. Accurate mass measurement was assured through an automated calibrator delivery system that continuously introduced a reference solution, containing masses of $m / z 121.0509$ (purine) and $m / z 922.0098$ (HP-921) in positive ESI mode; whereas $m / z 112.9856$ (TFA) and $m / z 922.009798$ (HP-921) in negative ESI mode. The capillary voltage was $\pm 4000 \mathrm{~V}$ for positive and negative ionization mode. The source temperature was $225^{\circ} \mathrm{C}$. The nebulizer and gas flow rate were $35 \mathrm{psig}$ and $11 \mathrm{~L} \cdot \mathrm{min}^{-1}$ respectively, fragmentor voltage to $75 \mathrm{~V}$ and a radiofrequency voltage in the octopole (OCT RF Vpp) of $750 \mathrm{~V}$.

All the solvents used were LC-MS grade. Purified water was obtained from Milli-Q Plus ${ }^{\mathrm{TM}}$ System from Millipore (Milford, MA, USA). Formic acid was purchased from Aldrich (St. Louis, MO, USA).

For the study, MassHunter Workstation Software LC/MS Data Acquisition version B.07.00 (Agilent Technologies, Santa Clara, CA, USA) was used for control and acquisition of all data obtained with UHPLC/MS-QTOF. 


\subsubsection{Data Handling}

UHPLC-MS data processing was performed by MassHunter Qualitative Analysis (Agilent Technologies, Santa Clara, CA, USA) Software version B.08.00 using "Molecular Feature Extraction (MFE)" to extract potential molecular features (MFs). The MFE algorithm creates a list of possible components that represent the full TOF mass spectral data features, which are the sum of co-eluting ions that are related by charge-state envelope, isotopic distribution and/or the presence of different adducts and dimmers. Several parameters of the algorithm were set for data extraction, applying 2000 counts as limits for the background noise. Moreover, the algorithm was applied to find co-eluting adducts for the same possible compound, selecting $+\mathrm{H},+\mathrm{Na},+\mathrm{K}$, and neutral water loss as possible adducts for positive ionization and $-\mathrm{H},+\mathrm{FA},+\mathrm{Cl}$ in negative ionization. Additionally, the "Generate Formula" option in the MassHunter Qualitative Analysis software was used to generate the empirical formula from accurate mass and isotopic pattern distribution to increase the confidence of compound annotation, with a very good score (about $97-99 \%$ ).

\subsubsection{Compound Identification}

The tentative identification of compounds was carried out by comparing their retention times and the accurate masses of features ( \pm 5-ppm error) against online databases, as FOODB, MetaCyc, CEU massmediator, and scientific bibliography.

To reach the possible annotation of peak 2, it was necessary to use the MetaCyc and to consult specific bibliography [44].

The identification of compounds corresponding to peaks $3,4,6,7$ and 8 was supported by comparison of their accurate masses in the databases for each compound, providing an accuracy error below $5 \mathrm{ppm}$. Specific bibliography was also consulted for their annotation [45-47]. To confirm the annotation of the peaks 4, 6 and 7, a MS/MS analysis was carried out and their final identification was supported using in silico prediction approaches, such as the freely available tool CFM-ID 3.0. The experimental MS/MS spectra were searched and scored against predicted spectra based on similarity.

Regarding peak 5, it was annotated after matching against different databases, based on its monoisotopic mass and molecular formula.

\subsection{Statistical Analysis}

One-way ANOVA with replicates was used to check the statistical differences in all data obtained. Prior to ANOVA analysis, homoscedasticity and normality of the variance was checked with Statgraphics plus 5.1 for Windows, meeting requirements for analysis. When significant differences appeared $(p<0.05)$ a Fisher test was used [48].

\section{Results}

\subsection{First Elicitation of Isoflavone in the Soybean: Concentration Optimization}

To test the capacity of the extract obtained from the metabolic elicitors by liquid-liquid separation to induce the isoflavone secondary metabolism, this extract was inoculated in the embryo cut of the soybean seeds at concentrations of 1000,100 and $10 \mu \mathrm{g} \cdot \mathrm{mL}^{-1}$, as is explained in Section 2.3. The fractions of 1000 and $100 \mu \mathrm{g} \cdot \mathrm{mL}^{-1}$ significantly elicited isoflavone production over both controls (Figure 2), and the seeds inoculated with $100 \mu \mathrm{g} \cdot \mathrm{mL}^{-1}$ recorded the highest induction. However, the seeds inoculated with $10 \mu \mathrm{g} \cdot \mathrm{mL}^{-1}$ showed an isoflavone synthesis very similar to that of control 1 and control 2 seeds or even less, in the case of malonyl genistin. Differences between the three concentrations were statistically significant. 
(a)

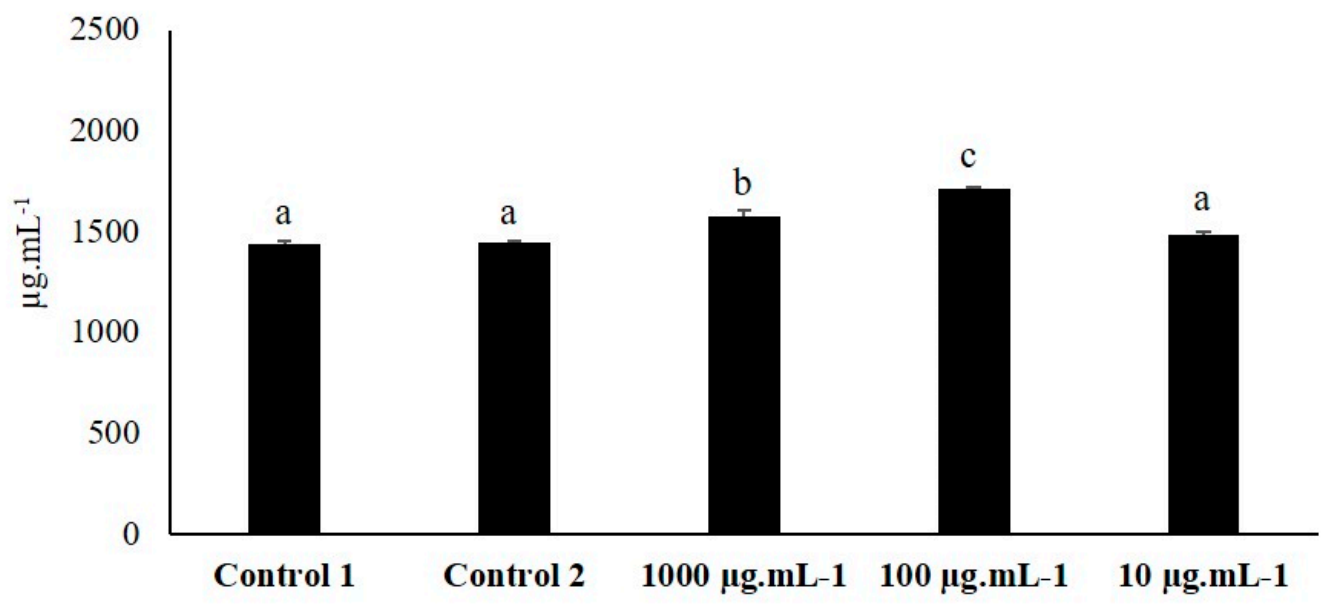

(b)

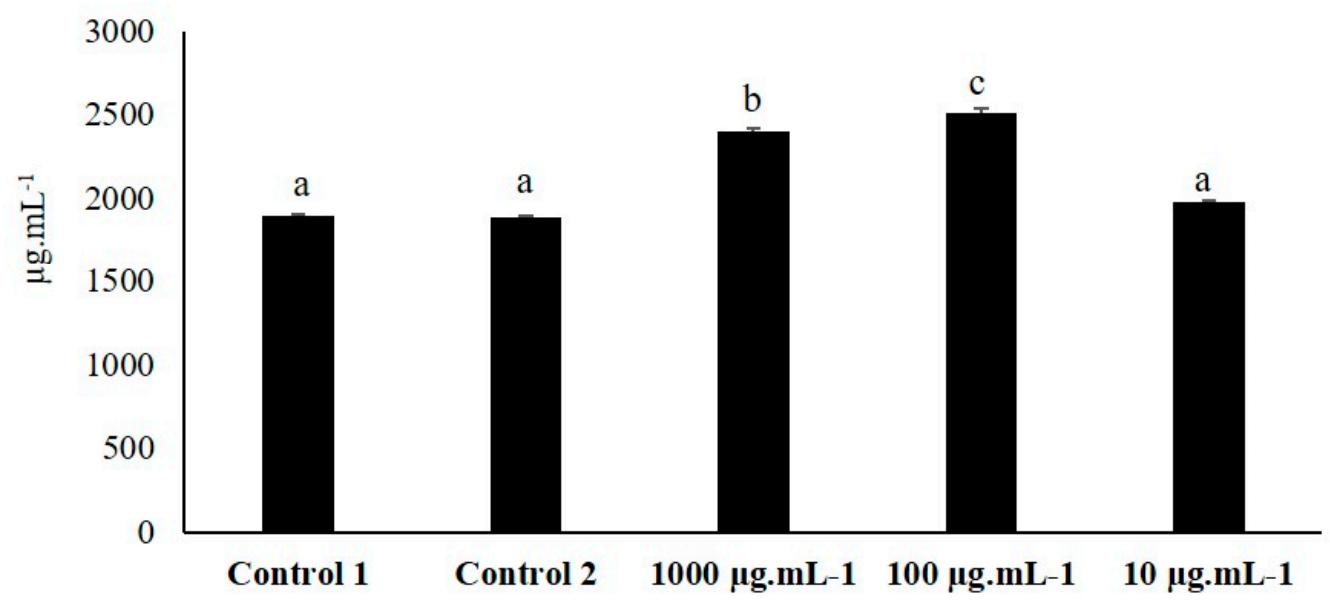

(c)

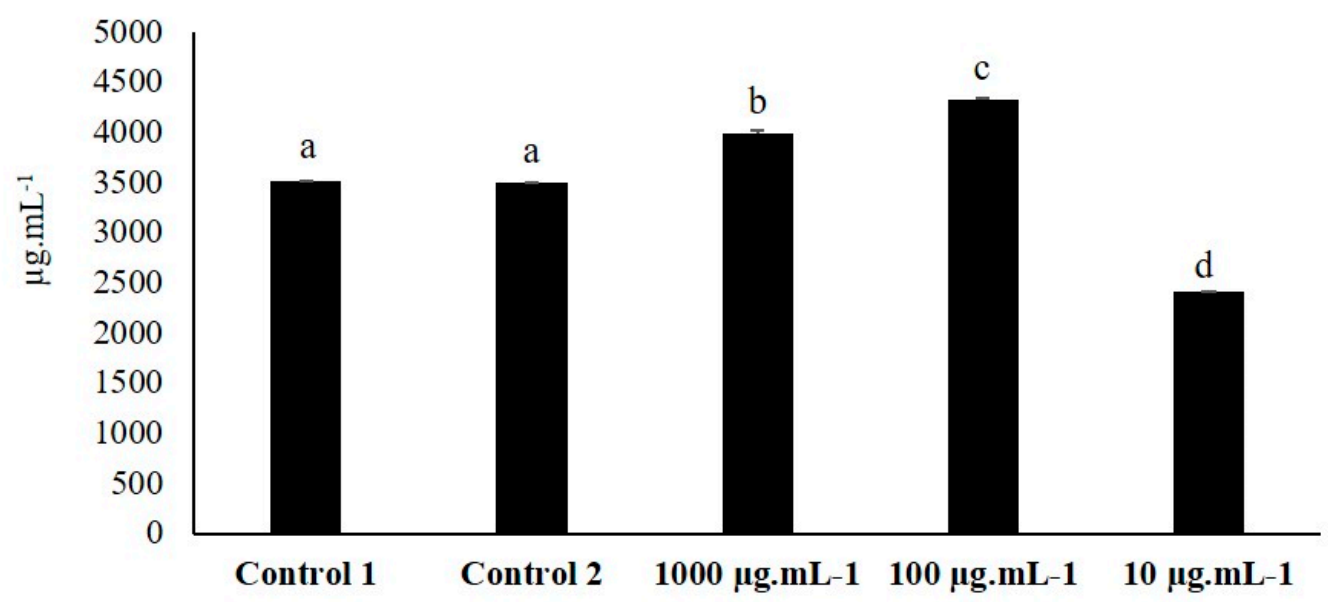

Figure 2. Daidzin (a), genistin (b) and malonyl genistin (c) production in the seeds inoculated with the extract obtained from the metabolic elicitors at 1000, 100 and $10 \mu \mathrm{g} \cdot \mathrm{mL}^{-1}$ and in control 1 (extract obtained from the liquid-liquid phase separation from the culture broth without bacteria) and control 2 (non-inoculated soybean seeds). The amount of isoflavones is expressed in $\mu \mathrm{g} \cdot \mathrm{mL}^{-1}(n=30$ soybean seeds $\times 3$ replicates). Different letters show significant statistical differences between treatments in each isoflavone $(p<0.05)$. Error bars correspond to standard deviation (SD). 
As there were not statistical differences between both controls in the synthesis of isoflavones, it was assumed that elicitation was due to the components of the metabolic elicitors and not the components present in the nutrient broth. For that reason, the control 1 was not further purified as the metabolic elicitor extract, and for the following elicitation experiments only control 1 was used.

\subsection{First TLC}

To visually assess the components present in the control $1(\mathrm{C})$ and in the four fractions (F1, F2, F3 and F4) obtained from the first VLC, a TLC was performed (Figure 3). In the TLC plate, only F1 and F2 showed separation between their components and both showed a common band at the top of the plate. Control 1 extract did not show band separation.

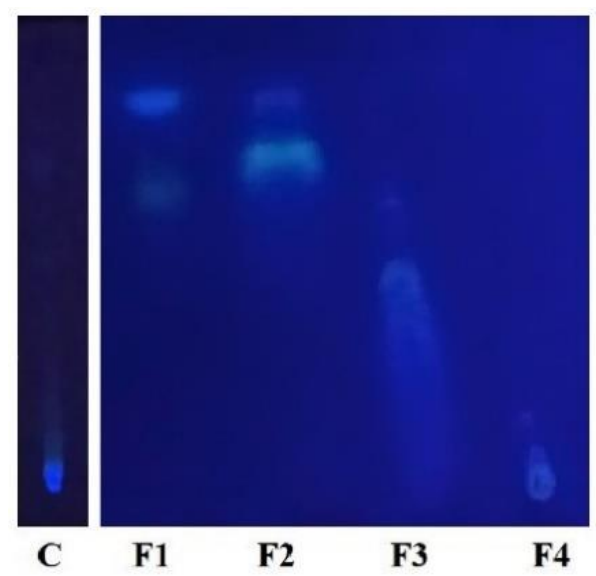

Figure 3. First TLC made with the control 1 (C) and the four fractions obtained from the fist VLC. F1 is the fraction obtained with hexane, F2 with dichloromethane, F3 with ethyl acetate and F4 with methanol.

\subsection{Second Elicitation of Isoflavone Metabolism in the Soybean}

According to the results obtained from the previous TLC, only F1 and F2 (of the first VLC) were tested in soybean seeds to check their ability to elicit isoflavone secondary metabolism (Figure 4), as F3 and F4 did not showed component fragmentation. The biosynthesis of the three isoflavones assessed was significantly higher in the seeds that were inoculated with F1 and F2 fractions compared to control 1 seeds. The highest elicitation values were obtained with F1.

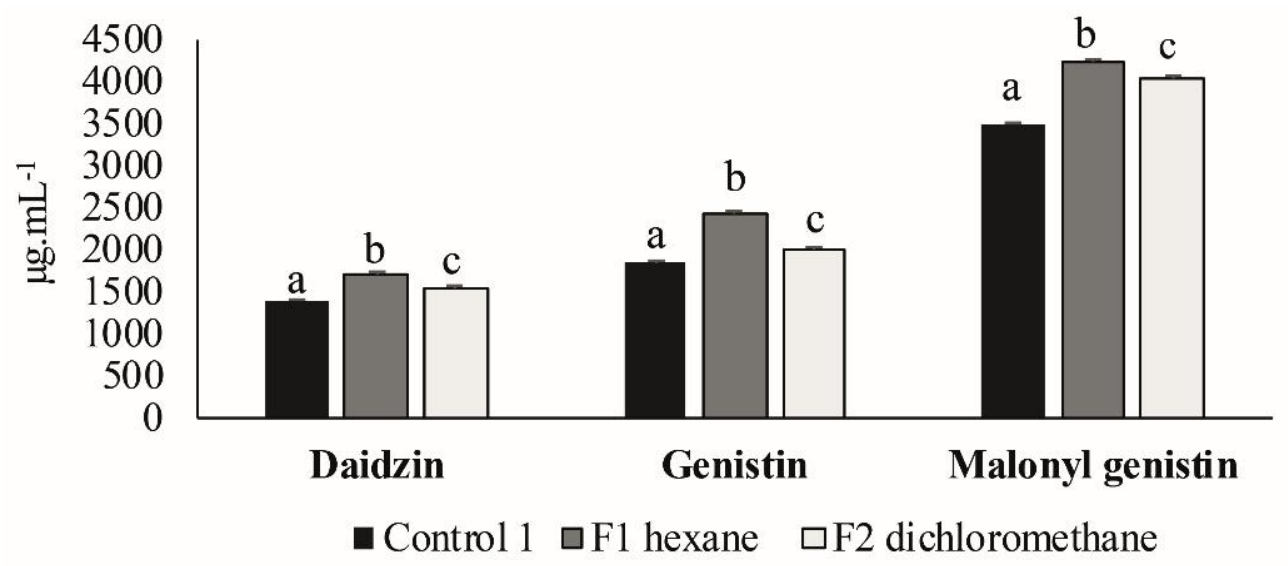

Figure 4. Daidzin, genistin and malonyl genistin production in the seeds inoculated with F1 and F2 obtained from the first VLC and in control 1 seeds. The amount of isoflavones is expressed in $\mu \mathrm{g} \cdot \mathrm{mL}^{-1}$ ( $n=30$ soybean seeds $\times 3$ replicates). Different letters show significant statistical differences between treatments in each isoflavone $(p<0.05)$. Error bars correspond to standard deviation (SD). 
When comparing this experiment with the first elicitation experiment, it was seen that the values of isoflavone elicitation obtained with the F1 and F2 fractions were similar to those obtained with the initial extract.

\subsection{Second TLC}

Since the highest elicitation values were obtained with F1 (Figure 4), a second VLC was performed to fragment and purify it. After the VLC, a TLC was made to visually assess the components present in the two fractions obtained (F1.1 and F1.2). F1.1 and F2.1 showed again a common band at the top of the TLC, bands of F1.1 being more intense than those of F2.1. These bands were very similar to those seen in the first TLC of F1 and F2 (Figure 5).

$2^{\text {nd }}$ TLC

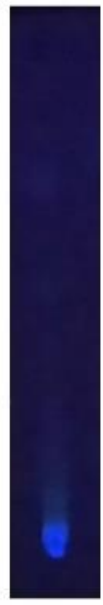

$\begin{array}{lll}\text { C } & \text { F1.1 } & \text { F2.1 }\end{array}$

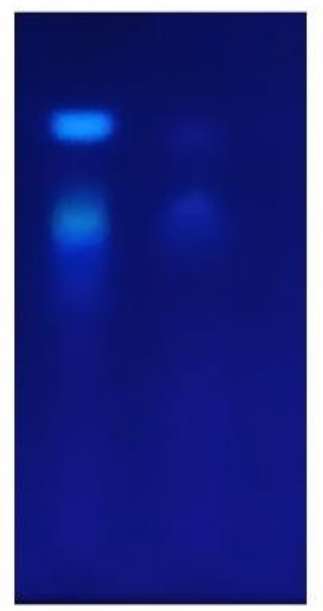

F1

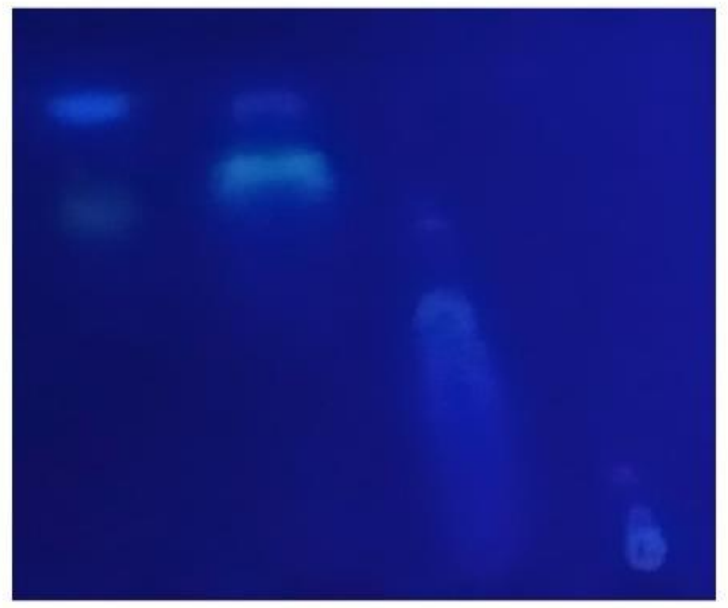

Figure 5. Comparison between the first and the second TLC. Second TLC was made with the two fractions obtained from the second VLC. F1.1 is the fraction obtained with hexane and F2.1 with dichloromethane.

\subsection{Third Elicitation of Isoflavone Metabolism in the Soybean}

As F1.1 fraction showed a similar but more intense band than F2.1 in the second TLC, it was chosen to check its capacity to elicit isoflavone secondary metabolism and it was inoculated in soybean seeds (Figure 6). Seeds inoculated with F1.1 had a significant higher isoflavone concentration than control 1 seeds.

When comparing this experiment with the first and the second elicitation experiments, it was seen that the values of isoflavone elicitation obtained with the F1.1 fraction were 1.2 times greater than those obtained with the F1 and F2 fractions and with the initial extract.

\subsection{Fourth Elicitation of Isoflavone Metabolism in the Soybean}

As F1.1-the fraction obtained from the second VLC - elicited the isoflavone metabolism, it was purified and the resultant fraction (Fp) was tested at concentrations of $100,10,1 \mathrm{and} 0.1 \mu \mathrm{g} \cdot \mathrm{mL}^{-1}$ in soybean seeds to check its capacity to elicit secondary metabolism of isoflavone (Figure 7). 
(a)

(b)
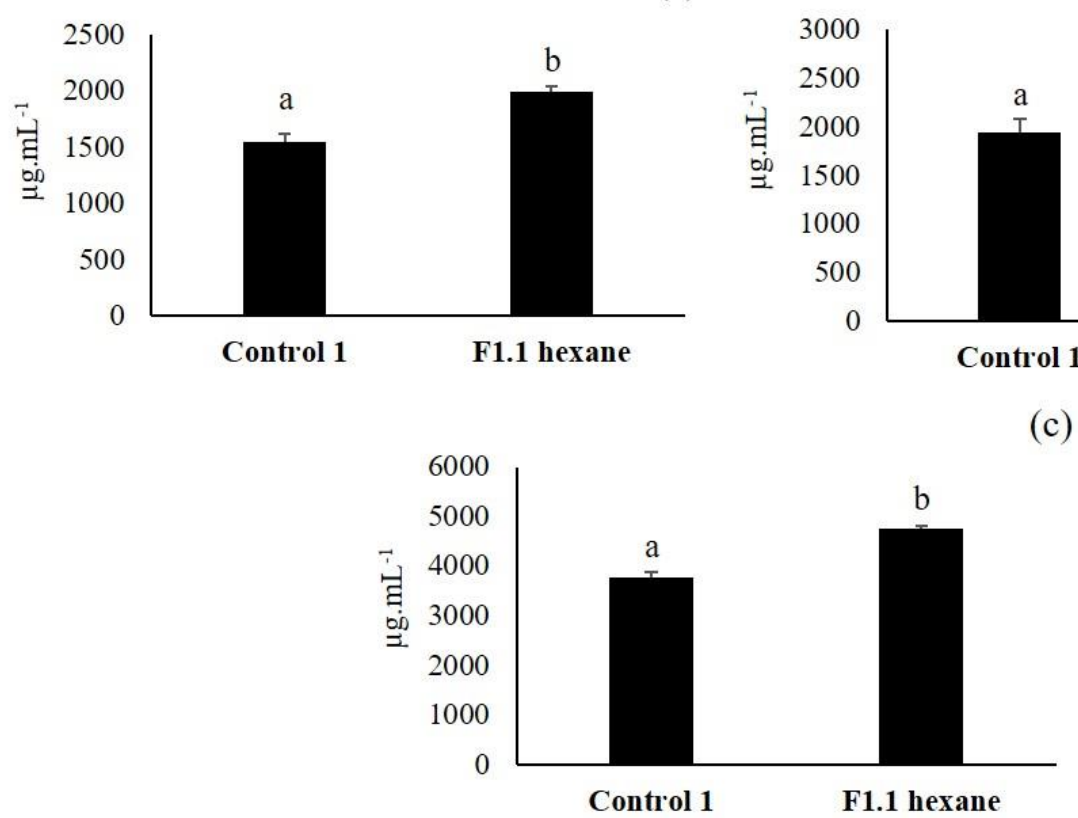

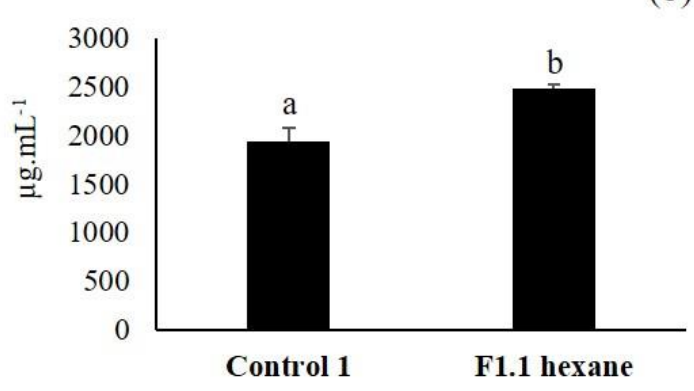

(c)

Figure 6. Daidzin (a), genistin (b) and malonyl genistin (c) production in the seeds inoculated with F1.1 obtained from the second VLC and in control 1 seeds. The amount of isoflavones is expressed in $\mu \mathrm{g} \cdot \mathrm{mL}^{-1}$ ( $n=30$ soybean seeds $\times 3$ replicates). Different letters show significant statistical differences between treatments in each isoflavone $(p<0.05)$. Error bars correspond to standard deviation (SD).

(a)
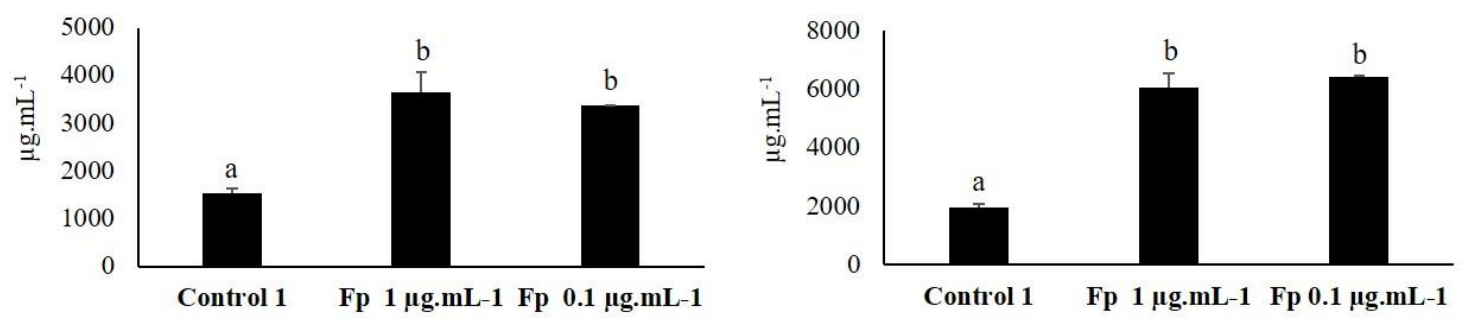

(c)

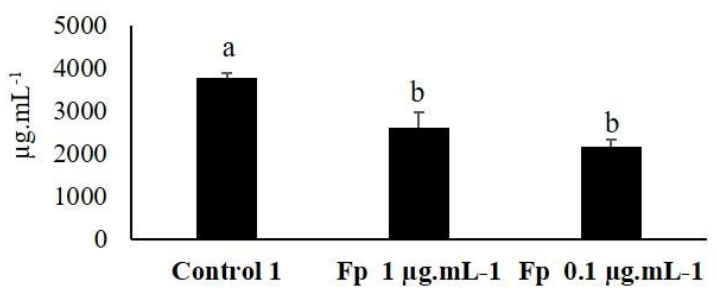

Figure 7. Daidzin (a), genistin (b) and malonyl genistin (c) production in the seeds inoculated with the purest fraction (Fp) obtained from F1.1 and in control 1 seeds. The amount of isoflavones is expressed in $\mu \mathrm{g} \cdot \mathrm{mL}^{-1}$ ( $n=30$ soybean seeds $\times 3$ replicates). Different letters show significant statistical differences between treatments in each isoflavone $(p<0.05)$. Error bars correspond to standard deviation (SD).

Seeds inoculated with 100 and $10 \mu \mathrm{g} \cdot \mathrm{mL}^{-1}$ were not able to germinate; they went black (data not shown) and they were not analyzed. However, in the seeds inoculated with 1 and $0.1 \mu \mathrm{g} \cdot \mathrm{mL}^{-1}$, the synthesis of daidzin and especially of genistin significantly increased with respect to control 1 . The synthesis of malonyl genistin decreased compared to control 1. No significant differences were seen between both concentrations in any of the three isoflavones.

When comparing the elicitation results obtained in this last experiment with the previous elicitation experiments (first, second and third), it was seen that the increases in the concentrations of daidzine 
and genistin triggered by Fp fraction (compared to the control 1) were more than double those produced by the F1.1, F1 and F2 fractions and the initial extract.

\subsection{ISR Experiment}

As the purest fraction (Fp) elicited the isoflavone metabolism in soybean seeds, it was then inoculated in $A$. thaliana seedlings at concentrations of 10 and $1 \mu \mathrm{g} \cdot \mathrm{mL}^{-1}$ to carry out an ISR experiment with the objective of checking its ability to protect plants against $P$. syringae pv. tomato DC 3000 infection. Results of protection against infection are shown in Figure 8.

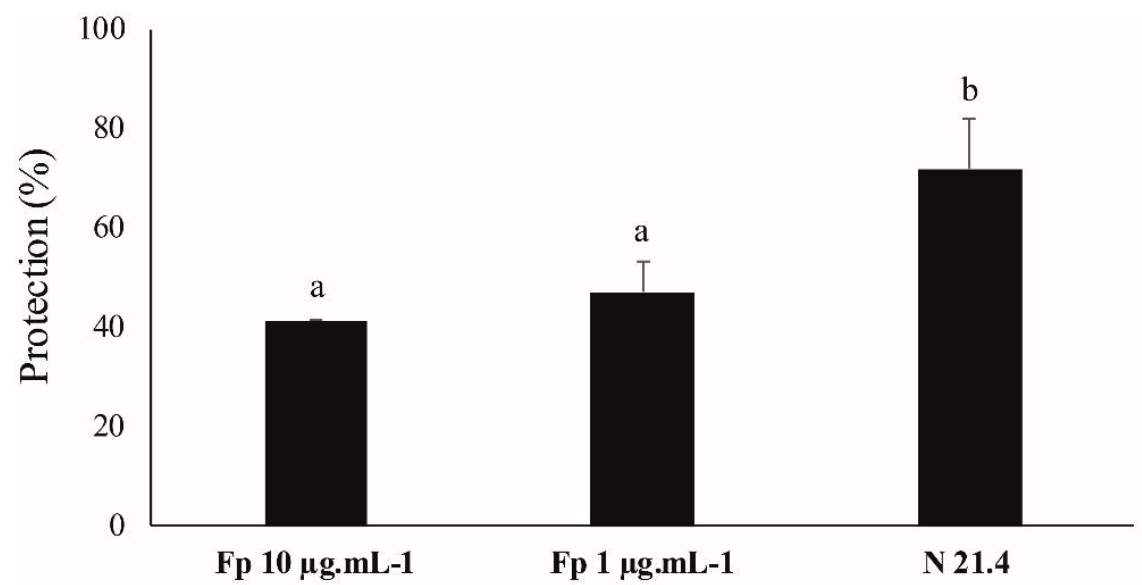

Figure 8. Protection (\%) against Pseudomonas syringae pv. tomato DC3000 in Arabidopsis thaliana seedlings elicited with the purest fraction (Fp) at 10 and $1 \mu \mathrm{g} \cdot \mathrm{mL}^{-1}$ and with the live strain P. fluorescens $\mathrm{N}$ 21.4. The percentage was calculated based on the number of leaves with disease symptoms to the total of leaves ( $n=12$ seedlings per replicate). Data were relativized to control 1 , which was considered as $0 \%$ protection. Different letters show significant statistical differences between treatments $(p<0.05)$. Error bars correspond to standard deviation (SD).

Protection rates against infection were between $40 \%$ and $50 \%$ for the Fp fraction and $70 \%$ for the live strain (used as positive control). No significant differences between the two concentrations of the Fp fraction were observed.

\subsection{RT-qPCR Experiment}

After the ISR experiment in A. thaliana, the differential expressions of marker genes of the salicylic acid (SA) and jasmonic/ethylene (JA/ET) signal transduction pathways were analyzed by qPCR (Table 3). The studied marker genes of the SA signaling pathway were PR1, NPR1 and ISC, and those of the JA/ET pathway were PDF1,PR3 and LOX 2. All these genes were measured at 6, 12 and 24 hapc.

Table 3. Differential gene expression (A. thaliana seedlings inoculated with the purest fraction at a concentration of 10 and $1 \mu \mathrm{g} \cdot \mathrm{mL}^{-1}$ vs. control 1$)$ at $6(n=12), 12(n=12)$ and $24(n=12)$ hapc.

\begin{tabular}{|c|c|c|c|c|c|c|c|}
\hline & & \multicolumn{3}{|c|}{$10 \mu \mathrm{g} \cdot \mathrm{mL}^{-1}$} & \multicolumn{3}{|c|}{$1 \mu \mathrm{g} \cdot \mathrm{mL}^{-1}$} \\
\hline & & 6 hapc & 12 hapc & 24 hapc & 6 hapc & 12 hapc & 24 hapc \\
\hline \multirow{3}{*}{ SA } & PR1 & $1.2 \pm 0.02 *$ & $5.35 \pm 0.06^{*}$ & 0 & $0.83 \pm 0$ & 0 & 0 \\
\hline & NPR1 & $2.44 \pm 0.21 *$ & $1.1 \pm 0.05$ & $0.73 \pm 0$ & $2.65 \pm 0.13$ * & $1.2 \pm 0.03 *$ & 0 \\
\hline & ICS & $1.66 \pm 0.12$ * & $0.66 \pm 0.01$ * & 0 & $2.02 \pm 0.03$ * & $1.47 \pm 0.03$ * & 0 \\
\hline \multirow{3}{*}{$\mathrm{JA} / \mathrm{ET}$} & PDF1 & $1.23 \pm 0.01 *$ & 0 & 0 & $2.36 \pm 0.02 *$ & 0 & 0 \\
\hline & LOX2 & $1.79 \pm 0.06^{*}$ & $0.73 \pm 0.03$ & 0 & $0.9 \pm 0.01$ & 0 & 0 \\
\hline & PR3 & $1.7 \pm 0 *$ & $0.72 \pm 0$ & 0 & $3.4 \pm 0.06^{*}$ & $1.31 \pm 0.1^{*}$ & 0 \\
\hline
\end{tabular}

Asterisks represent statistically significant differences $(p<0.05)$ with respect to control 1 (differential expression of 1 ) within each sampling time. 
The differential expression of marker genes of the SA signaling pathway at both concentrations (10 and $1 \mu \mathrm{g} \cdot \mathrm{mL}^{-1}$ ) decreased from 6 to 12 hapc, except for $P R 1$, with $10 \mu \mathrm{g} \cdot \mathrm{mL}^{-1}$, which increased. With $1 \mu \mathrm{g} \cdot \mathrm{mL}^{-1}, P R 1$ did not show significant differential expression, while NPR1 and ICS showed slightly higher expression with $1 \mu \mathrm{g} \cdot \mathrm{mL}^{-1}$ than with $10 \mu \mathrm{g} \cdot \mathrm{mL}^{-1}$ at both sampling moments. None of the genes showed differential expression at 24 hapc.

Marker genes of the JA/ET signaling pathways, at both concentrations, only showed significant differential expression at 6 hapc, except $P R 3$, which also showed significant differential expression at 12 hapc with $1 \mu \mathrm{g} \cdot \mathrm{mL}^{-1}$. The expressions of PDF1 and PR3 were higher with the concentration of $1 \mu \mathrm{g} \cdot \mathrm{mL}^{-1}$. None of the genes showed differential expression at 24 hapc.

\subsection{Characterization by UHPLC/ESI-QTOF-MS}

The purest fraction (Fp) obtained from the metabolic elicitors of P. fluorescens N 21.4 was analyzed by UHPLC/ESI-QTOF-MS, as described in Material and Methods, leading to the characterization of eight peaks (corresponding to eight compounds). Figure 9 shows the extracted ion chromatograms (EICs) provided by the analysis of the extract in the positive ionization mode, which has proved to be more efficient and sensitive than in negative mode for compound characterization, and located within the chromatographic retention interval 14-17.5 min. The tentatively identified compounds, classified by families, and the main parameters that support their annotation, are listed in Table 4 .

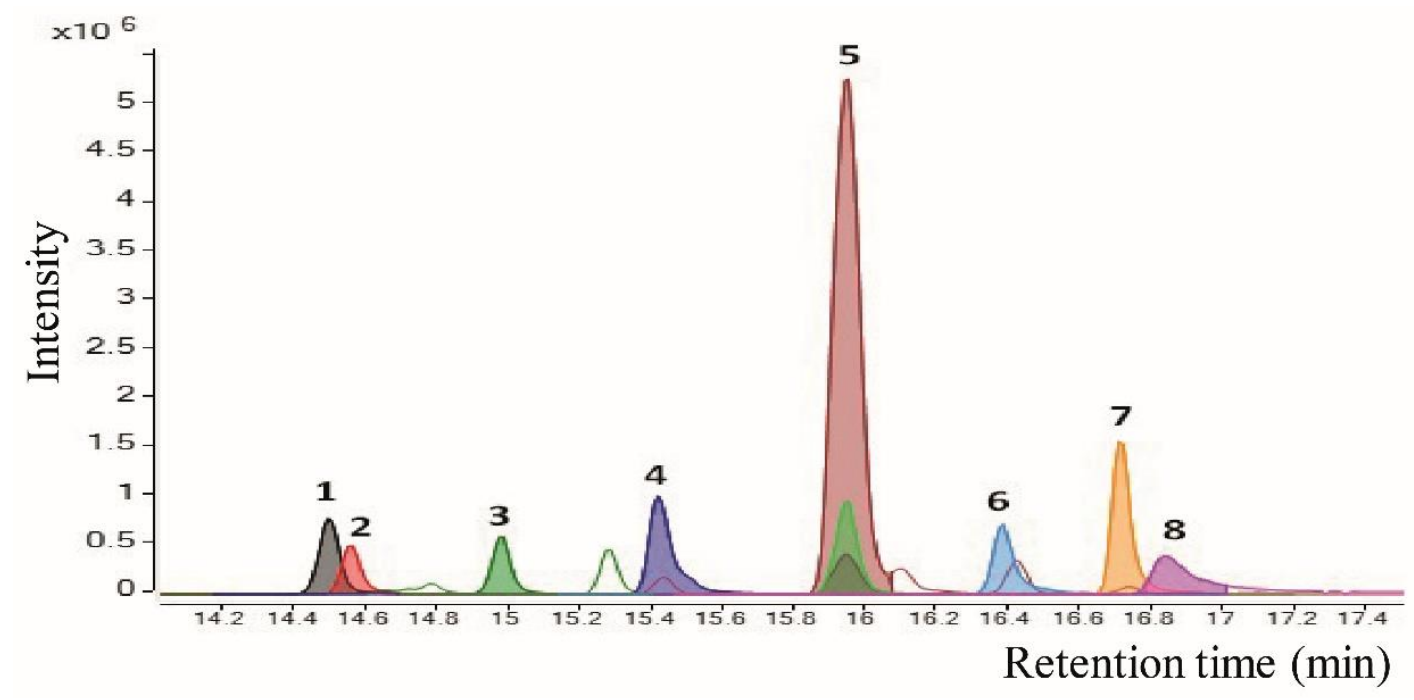

Figure 9. Overlay of the extracted ion chromatograms (EICs) for compounds present in the extract of the purest fraction. The enlargements of a part of the chromatogram are shown from 14.0 to $17.5 \mathrm{~min}$.

In the research proposed, eight compounds (Figure 9) were detected in the extract of the purest fraction-among them, one alkaloid (peak 2), two amino lipids (peaks 3 and 8), a terpenoid (peak 5) and three aryl alkylamines (peaks 4, 6 and 7).

According to its monoisotopic mass molecular formula and by consulting a specific database and bibliography [44], the annotation Ambiguine P (a cycloheptane-containing member of the hapalindole alkaloid) could be possible for the compound corresponding to peak 2.

The family that encompasses amino derivatives was remarkable in the extract due to the number of identified compounds (compounds 3, 8, 4, 6 and 7 of the Table 4). The most important compounds in this family were those related to long chain dialkyl, monalkyl and aryl alkylamines, saturated and unsaturated. In this study, peak 3, was annotated as Sphinganine C17 and peak 8 was annotated as $\mathrm{N}$-Methyl- $\mathrm{N}$-stearylamine (1-nonadecanamine). The peaks 4,6 and 7 , were annotated as arylalkylamines and their identification was supported by their MS/MS spectra (see Figure S1 of Supplementary Material). 
Regarding peak 5, (see Figure S2 of Supplementary Material for experimental MS/MS spectra), and considering different databases based on its monoisotopic mass and molecular formula, two terpenoid annotations could be considered to be related: the sesquiterpenoid 4-O-methylmelleolide (alkyl resorcinol ester derivative) [49], and the diterpenoid 2-Acetoxy-3-deacetoxycaesaldekarin E (neocaesalpin AH) [50].

Table 4. Retention times, mass spectral data and characterizations of the detected compounds in the UHPLC/ESI-QTOF-MS analysis in positive and negative ionization modes.

\begin{tabular}{|c|c|c|c|c|c|c|}
\hline$n^{\circ}$ & Tentative Annotation ${ }^{a}$ & $\underset{\text { (min) }}{\mathbf{R t}}$ & $\begin{array}{l}\text { Molecular } \\
\text { Formula }\end{array}$ & $\begin{array}{l}\text { Monoisotopic } \\
\text { Mass }\end{array}$ & $m / z$ Experimental & Fragments (MS2) \\
\hline \multicolumn{7}{|c|}{ Unknowns } \\
\hline 1 & Unknown & 14.5 & $\mathrm{C}_{17} \mathrm{H}_{14} \mathrm{~N}_{2} \mathrm{~S}$ & 278.0878 & {$[\mathrm{M}+\mathrm{Na}]^{+}=301.0762$} & - \\
\hline \multicolumn{7}{|c|}{ Alkaloids } \\
\hline 2 & - & 14.6 & $\mathrm{C}_{25} \mathrm{H}_{29} \mathrm{NO}$ & 359.2249 & {$[\mathrm{M}+\mathrm{H}]^{+}=360.2333$} & - \\
\hline \multicolumn{7}{|c|}{ Amino lipids } \\
\hline 3 & Sphinganine C17 & 14.9 & $\mathrm{C}_{17} \mathrm{H}_{37} \mathrm{NO}_{2}$ & 287.2824 & $\begin{array}{c}{[\mathrm{M}+\mathrm{H}]^{+}=288.2999} \\
{[\mathrm{M}+\mathrm{Na}]^{+}=310}\end{array}$ & - \\
\hline 8 & 1-Nonadecanamine & 16.8 & $\mathrm{C}_{19} \mathrm{H}_{41} \mathrm{~N}$ & 283.3239 & {$[\mathrm{M}+\mathrm{H}]^{+}=284.3320$} & - \\
\hline
\end{tabular}

\begin{tabular}{|c|c|c|c|c|c|c|}
\hline 5 & - & 15.9 & $\mathrm{C}_{24} \mathrm{H}_{30} \mathrm{O}_{6}$ & 414.2042 & $\begin{array}{c}{[\mathrm{M}+\mathrm{Na}]^{+}=437.1946} \\
{[\mathrm{M}+\mathrm{H}]^{+}=415.2121} \\
{[\mathrm{M}+\mathrm{K}]^{+}=453.1680} \\
{[2 \mathrm{M}+\mathrm{Na}]^{+}=851.3989} \\
{[\mathrm{M}+\mathrm{FA}-\mathrm{H}]^{-}=459.2029}\end{array}$ & $\begin{array}{l}\text { 338.4838, 325.1891, } \\
\text { 277.1818, 141.4137, } \\
104.2879,90.6591\end{array}$ \\
\hline \multicolumn{7}{|c|}{ Arylalkylamines } \\
\hline 4 & $N$-benzyl-1-tetradecanamine & 15.4 & $\mathrm{C}_{21} \mathrm{H}_{37} \mathrm{~N}$ & 303.2926 & {$[\mathrm{M}+\mathrm{H}]^{+}=304.3003$} & $\begin{array}{c}212.2379,91.0544, \\
65.0383,58.0652\end{array}$ \\
\hline 6 & $N$-benzyl-1-hexadecanamine & 16.4 & $\mathrm{C}_{23} \mathrm{H}_{41} \mathrm{~N}$ & 331.3239 & {$[\mathrm{M}+\mathrm{H}]^{+}=332.3320$} & $\begin{array}{c}240.2682,91.0544 \\
69.0694,58.0652\end{array}$ \\
\hline 7 & $N$-benzyl-1-octadecanamine & 17.3 & $\mathrm{C}_{25} \mathrm{H}_{46} \mathrm{~N}$ & 325.3709 & {$[\mathrm{M}+\mathrm{H}]^{+}=360.3622$} & $\begin{array}{c}268.2993,91.0544 \\
85.0652,58.0652\end{array}$ \\
\hline
\end{tabular}

${ }^{a}$ Compounds identified compared with data reported in literature and online databases.

\section{Discussion}

The pressure on the demand for agriculture practices that improve yield and quality food, linked to increasing concerns about sustainability, has led to the emerge of studies about new substances that substitute environmentally harmful or health risky phytosanitaries for more ecofriendly and effective plant inoculants able to enhance plants' immune systems and plants' resistance to pests and abiotic stress. This current development of biotechnological alternatives in the agronomic field has been concentrated on the use of more efficient tools with low biological and environmental repercussions [23]. One of these reliable and non-polluting tools is the use of inductors or elicitors from beneficial microorganisms [13]. Therefore, the present work was focused on isolating, purifying and identifying the compound or set of elicitor compounds extracted from the metabolism of the beneficial rhizobacterium P. fluorescens $\mathrm{N}$ 21.4, which were able to elicit isoflavone secondary metabolism in soybean seeds and to induce systemic resistance in A. thaliana.

Our results have shown that metabolic elicitor fractions extracted from the strain P. fluorescens $\mathrm{N}$ 21.4 were able to enhance the synthesis of isoflavones in soybean seeds between 1.2 to 3.2 times more than controls, demonstrating its potential to elicit secondary defense metabolism (Figures 4, 6 and 7). This capacity of elicitation was increased while the purification and concentration of the fractions (from F.1 at $100 \mu \mathrm{g} \cdot \mathrm{mL}^{-1}$ to Fp at $1-0.1 \mu \mathrm{g} \cdot \mathrm{mL}^{-1}$ ) progressed [51].

The technique provided in the present work to verify the elicitation of secondary metabolism in the plant was an effective, simple and very fast technique, since it allowed checking the eliciting 
capacity of the fractions inoculated in soybean seeds in less than $90 \mathrm{~h}$. This fast and effective system would allow one to carry out rapid screenings to search for new eliciting compounds in future research.

On the other hand, the results obtained in the ISR experiment in $A$. thaliana against the pathogen P. syringae pv. tomato DC 3000 supported the statement that the metabolic elicitors of the strain N 21.4 have great potential to increase plant resistance, since protection rates between 40 to $50 \%$ were seen (Figure 8). The ISR experiment also revealed a simultaneous activation of both SA and JA/ET signaling pathways, since high levels of PR1, NPR1 and ICS (SA marker genes), and PDF1, LOX 2 and PR3 (JA/ET marker genes) were seen. Hence, it has been again demonstrated that these two pathways are not necessarily antagonistic, as previously indicated by some authors [52,53]. The importance of high concentrations of SA and JA to trigger defensive responses mediated by both hormones is nowadays widely accepted $[3,54]$. Furthermore, this experiment showed a very rapid ISR response, having high values of differential gene expression at 6 hapc. Despite not having seen big differences between both concentrations of inoculation $\left(1\right.$ and $\left.10 \mu \mathrm{g} \cdot \mathrm{mL}^{-1}\right)$, a trend of greater differential expression and higher protective rates against pathogen infection were seen when plants were inoculated with $1 \mu \mathrm{g} \cdot \mathrm{mL}^{-1}$. The genes that showed the greatest differences of expression between the two concentrations were ICS and PR3 genes, which were doubly expressed in the plants inoculated with $1 \mu \mathrm{g} \cdot \mathrm{mL}^{-1}$. From a commercial point of view, having a noticeable effect at such a low concentration is very interesting when the intention is making effective, but at the same time affordable plant inoculants.

After the exhaustive analysis by UHPLC/ESI-QTOF-MS to identify and characterize the compounds responsible for the elicitation, eight peaks corresponding to eight different compounds were detected (Figure 9). The groups of compounds found corresponded with an alkaloid, two amino lipids, a terpenoid and three arylalkylamines. An unknown compound was also detected, but it was impossible to elucidate its identity since it was not found described in the literature nor in databases.

A tentative annotation was found for compound corresponding to peak 2, the alkaloid nature one, after consulting the MetaCyc database and specific bibliography [45]. This compound could be described as Ambiguine $\mathrm{P}$, a cycloheptane-containing member of the hapalindole alkaloid. Hapalindole-type natural products are structurally diverse terpenoid indole alkaloids that, to date, have only been described as secondary metabolites produced by cyanobacteria. They have a wide range of biological activities, including insecticidal [55], antibacterial and antifungal [56-58]. Literature does mention other alkaloid compounds produced by P. fluorescens, such as pyrrolnitrin or hydropyridine-type compounds that also show antibiotic and antifungal activity [28,59]. However, hapalindole-type natural products have never been described in P. fluorescens; hence, this result would require further investigation to be more conclusive.

Compounds corresponding to peaks 3 and 8 were seen to be amino lipid compounds. Sphinganine C17 (peak 3) is a type of sphingolipid that the literature describes with a signaling function in plants subjected to biotic and abiotic stress [45-47]. In bacteria, sphingolipids are specific membrane lipids each with a monounsaturated long-chain, the sphingosine, and their biological role has not been fully understood yet. Few bacteria have been described able to synthesize sphingolipids and some of these are cytophaga-flavobacterium-bacteroidetes group bacteria, $\alpha$-proteobacteria and $\delta$-proteobacteria (Bdellovibrio bacterivorous, Cystobacter fuscus, Myxococcus stipitatus, Sorangium cellulosum and Myxococcus xanthus [47]. However, it has been seen that lipopolysaccharide of Gram-negative bacteria shows structural and functional resemblance to sphingolipids of the above-cited bacteria and even to sphingolipids produced by eukaryotes. That is why in the work of Heaver et al. [60] it was proposed that as sphingolipid produced by bacteria are very similar to those produced by their eukaryotic hosts, they could influence in their hosts immune responses.

The role that sphingolipids play in plant-microorganism interactions and as bioactive elicitors that initiate defensive responses in plants has begun to be studied [47]. However, Giorni et al. [61] and Dall'Asta et al. [62] have already established a possible relationship between sphingolipids produced by various maize hybrids with Fusarium verticillioides infection. 
In contrast to eukaryotes, where sphingolipids functions have been extensively studied, very little is known about sphingolipids in bacteria and their functions in the plant-pathogen relationship. Some of the sphingolipids-producing bacteria have been found to be abundant in the phyllosphere of plants [63], which hints that sphingolipid production by bacteria may be relevant for them.

This study was the first synthesis of sphingolipids in the genus Pseudomonas, and its relationship with the triggering of secondary metabolism is cited. However, it is clear that more research is needed on this unknown subject.

The other amino lipid nature compound, the one corresponding to peak 8 , was tentatively identified as $\mathrm{N}$-methyl- $\mathrm{N}$-stearylamine (1-nonadecanamine). This compound has been reported in some works for its antimicrobial potential, being more commonly found in plant species [64-66]. It has been also found as a secondary metabolite of Brevibacterium casei [67] and Saccharomyces cerevisiae, with antibiotic activity against Proteus mirabilis [68]. Compound 8 has also been described in other bacterial and plants extracts as a structural constituent of biological membranes, and the results were consistent with those of previous literature reports [69].

The amino derivatives corresponding to arylalkylamines (peaks 4, 6 and 7) have been generally described as dialkyl and monalkyl amines, saturated and unsaturated. Further investigations will be necessary to determine whether such alkylamines may be considered functional analogs of sphingosine and which may be primarily expressed among the pathways associated with sphingolipid metabolism.

For the last identified compound, the most abundant one (peak 5), two possible annotations within the group of terpenoids were found: the sesquiterpenoid 4-O-methylmelleolide (alkyl resorcinol ester derivative) [49] and the diterpenoid 2-acetoxy-3-deacetoxycaesaldekarin E (neocaesalpin AH) [50].

Terpenoids are generally considered as secondary metabolites produced by plant or fungi, but recent sequencing of the bacterial genome and bioinformatics analyses of bacterial proteins have revealed the presence of these metabolites in bacteria [70,71]. In bacteria, terpenoids can be found in the form of essential oils or aromatic constituents and some have antibiotic and antifungal activities [72,73].

Despite terpene biosynthetic pathways in bacteria being considered ubiquitous, few bacterial terpenes have been identified, and their biosynthesis is still poorly understood [74]. The antiSMASH tool lists more than 4000 bacterial terpene biosynthetic gene clusters [75], but only 127 have been identified and deposited in the MIBiG database (repository of characterized biosynthetic gene clusters) [76], so far. However, literature has revealed the production of 2,5-dialkylresorcinol compounds that exhibit antifungal and antibacterial activities in specific strains of Pseudomonas spp. [77,78]. These are compounds very similar to the compound proposed by our first annotation option (alkyl resorcinol ester derivative).

The induction of systemic resistance in A. thaliana and the elicitation of the secondary isoflavone metabolism in soybean seeds may have been due to the effect of the sesquiterpenoid compound present in the extract of the purest fraction of the metabolic elicitors of P. fluorescens N 21.4-it being the majority in the fraction - or due to a synergy between all the compounds that have been identified. Nevertheless, it is clear that deeper research will be necessary in the future to carry out more specific studies with the identified compounds in order to better characterize them and their effects in the plants.

By comparing the fractions extracted from the metabolic elicitors with the control 1, which was extracted in the same way as the fractions, it has also been possible to affirm that the inducing and protective effects were due to the compounds present in the metabolic elicitors of the bacterium and not to any compound present in the nutrient broth. Furthermore, it has been seen that the beef extract used in the nutrient broth is a concentrate of water-soluble compounds, which remained in the aqueous phase, which was discarded in the initial liquid-liquid separation.

In our work we tested the capacity to induce systemic resistance and the capacity to elicit secondary defensive metabolism in plants, but in view of our promising results and having some compounds with putative antibiotic and/or antifungal activity, further research will be performed to test their potential as antibiotics or antifungals against common pathogens present in agricultural systems. Furthermore, 
we will study the possibility of including all or some of these compounds, derivatives of the secondary metabolism of the P. fluorescens N 21.4, as commercial plant inoculants.

\section{Conclusions}

The results of the present study demonstrated that the fractions obtained by VLC from the metabolic elicitors of $P$. fluorescens N 21.4 induced systemic resistance in $A$. thaliana seedlings against the pathogen P. syringae pv. tomato DC3000, being able to trigger the two signaling pathways of the defensive response (SA and JA/ET) very quickly and at very low concentrations. These fractions also boosted the secondary defensive metabolism of isoflavones in soybean seeds.

Taking into account our results and those provided in previously published works, it can be concluded that the metabolic elicitors of P. fluorescens $\mathrm{N} 21.4$ could be used to create new plant inoculants to be introduced in agricultural practices, minimizing the scope of chemical control, and thus advancing the development of ecofriendly agricultural tools. The purified and identified compounds of the metabolic elicitor fraction (mixed or individually), could result in commercial products of biological origin being applied to crops in the near future, since many of them have putative antibiotic and/or antifungal potential.

Furthermore, the elicitor screening system carried out in soybean seeds to specifically study the metabolic elicitors' effect on isoflavone metabolism, is a doubly fast and efficient system that allows one to verify the elicitation of secondary metabolism in the plant in less than $90 \mathrm{~h}$, which will be very useful for future elicitor compound screenings.

In this work, in Pseudomonas fluorescens, we described the synthesis of certain compounds that had not been described in the literature to date, such as sphingolipids and hapalindole-type natural products.

Supplementary Materials: The following are available online at http://www.mdpi.com/2223-7747/9/8/1020/s1, Figure S1. Experimental MS/MS spectra for the aryl alkylamines detected in the extract at the collision energy $(30 \mathrm{eV})$ in positive; Figure S2. Experimental MS/MS spectra at the collision energy $(30 \mathrm{eV})$ in positive and negative.

Author Contributions: The results are part of the doctoral thesis of H.M.-R. whose directors and supervisors were: J.A.L. and F.J.G.-M. All authors designed the experiments described in the manuscript. H.M.-R., M.O.P.N. and G.A. carried out the metabolic elicitor fractionation and the experiments done with soybean seeds; H.M.-R. and J.A.L. performed the experiment done with A. thaliana, the collection of samples and the subsequent analyses; H.M.-R., J.A.L. and A.G. did the HPLC analyses; H.M.-R., J.A.L. and A.G. wrote the main manuscript; and all authors reviewed the manuscript. All authors have read and agreed to the published version of the manuscript.

Funding: This research was funded by Ministerio de Economía y Competitividad of Spain grant number AGL-2013-45189-R. And the APC was funded by Universidad San Pablo-CEU Universities.

Conflicts of Interest: The authors declare no conflict of interests.

\section{Abbreviations}

$\begin{array}{ll}\text { DMSO } & \text { Dimethyl sulfoxide } \\ \text { ESI } & \text { Electrospray ionization source } \\ \text { Hapc } & \text { Hours after pathogen challenge } \\ \text { ISR } & \text { Induced systemic resistance } \\ \text { JA/ET } & \text { Jasmonic acid/Ethylene } \\ \text { QTOF-MS } & \text { Quadrupole time-of-flight mass spectrometry } \\ \text { SA } & \text { Salicylic acid } \\ \text { TLC } & \text { Thin layer chromatography } \\ \text { UHPLC } & \text { Ultra high performance liquid chromatography } \\ \text { VLC } & \text { Vacuum liquid chromatography }\end{array}$

\section{References}

1. Miller, R.; Ge Costa Alves, G.S.; Van Sluys, M.A. Plant immunity: Unravelling the complexity of plant responses to biotic stresses. Ann. Bot. 2017, 119, 681-687. [CrossRef] [PubMed] 
2. Van Loon, L.C.; Bakker, P.; Pieterse, C.M.J. Systemic resistance induced by rhizosphere bacteria. Annu. Rev. Phytopathol. 1998, 36, 453-483. [CrossRef] [PubMed]

3. Pieterse, C.M.J.; Zamioudis, C.; Berendsen, R.L.; Weller, D.M.; Van Wees, S.C.; Bakker, P.A. Induced Systemic Resistance by Beneficial Microbes. Annu. Rev. Phytopathol. 2014, 52, 347-375. [CrossRef] [PubMed]

4. Mauch-Mani, G.; Baccelli, I.; Luna, E.; Flors, V. Defense Priming: An Adaptive Part of Induced Resistance. Annu. Rev. Plant Biol. 2017, 68, 485-512. [CrossRef]

5. Leite, B.; Roncato, L.D.B.; Pascholati, S.F.; Lambais, M.R. Reconhecimento e transdução de sinais moleculares em interações planta-fungos fitopatogênicos. RAPP 1997, 5, 235-280.

6. Pascholati, S.F. Indução de resistência: Opção para o controle de doenças de plantas no século XXI. Summa Phytopathol. 2003, 29, 115-116.

7. Van Loon, L.C.; Rep, M.; Pieterse, C.M. Significance of inducible defense-related proteins in infected plants. Annu. Rev. Phytopathol. 2006, 44, 135-162. [CrossRef]

8. Ebel, J.; Cosio, E.G. Elicitors of plant defense responses. Int. Rev. Cytol. 1994, 148, 1-36. [CrossRef]

9. Hahn, M.G. Microbial elicitors and their receptors in plants. Ann. Rev. Phytopathol. 1996, 34, $387-412$. [CrossRef]

10. Nürnberger, T. Signal perception in plant pathogen defense. Cell. Mol. Life Sci. 1999, 55, 167-182. [CrossRef]

11. Gómez-vásquez, R.O.C.Í.O.; Day, R.; Buschmann, H.; Randles, S.; Beeching, J.R.; Cooper, R.M. Phenylpropanoids, phenylalanine ammonia lyase and peroxidases in elicitor-challenged cassava (Manihot esculenta) suspension cells and leaves. Ann. Bot. 2004, 94, 87-97. [CrossRef] [PubMed]

12. Ramirez-Prado, J.S.; Abulfaraj, A.A.; Rayapuram, N.; Benhamed, M.; Hirt, H. Plant Immunity: From Signalling to Epigenetic Control of Defense. Trends Plant Sci. 2018, 9, 833-844. [CrossRef]

13. Gozzo, F.; Faoro, F. Systemic Acquired Resistance (50 Years after Discovery): Moving from the Lab to the Field. J. Agric. Food Chem. 2013, 61, 12473-12491. [CrossRef] [PubMed]

14. Wu, G.; Liu, Y.; Xu, Y.; Zhang, G.; Shen, Q.; Zhang, R. Exploring elicitors of the beneficial rhizobacterium Bacillus amyloliquefaciens SQR9 to induce plant systemic resistance and their interactions with plant signaling pathways. Mol. Plant Microbe Interact. 2018, 31, 560-567. [CrossRef]

15. Baker, B.; Zambryski, P.; Staskawicz, B.; Dinesh-Kumar, S.P. Signaling in plant-microbe interactions. Science 1997, 276, 726-733. [CrossRef] [PubMed]

16. Sarma, B.K.; Mehta, S.; Singh, H.B.; Singh, U.P. Plant growth-promoting rhizobacteria elicited alteration in phenolic profile of chickpea (Cicer arietinum) infected by Sclerotium rolfsii. Phytopathol. J. 2002, 150, 277-282. [CrossRef]

17. Ramos-Solano, B.; Algar, E.; Garcia-Villaraco, A.; Garcia-Cristobal, J.; Lucas Garcia, J.A.; Gutierrez-Manero, F.J. Biotic elicitation of isoflavone metabolism with plant growth promoting rhizobacteria in early stages of development in Glycine max var. Osumi. J. Agric. Food Chem. 2010, 58, 1484-1492. [CrossRef]

18. Martin-Rivilla, H.; Garcia-Villaraco, A.; Ramos-Solano, B.; Gutierrez-Manero, F.J.; Lucas, J.A. Extracts from cultures of Pseudomonas fluorescens induce defensive patterns of gene expression and enzyme activity while depressing visible injury and reactive oxygen species in Arabidopsis thaliana challenged with pathogenic Pseudomonas syringae. AoB Plants 2019, 11, 1-9. [CrossRef]

19. De Oliveira, A.G.; Spago, F.R.; Simionato, A.S.; Navarro, M.O.P.; da Silva, C.S.; Barazetti, A.R.; Novello, C.R. Bioactive organocopper compound from Pseudomonas aeruginosa inhibits the growth of Xanthomonas citri subsp. citri. Front Microbiol. 2016, 7, 1-12. [CrossRef]

20. Ngoroyemoto, N.; Gupta, S.; Kulkarni, M.G.; Finnie, J.F.; Van Staden, J. Effect of organic biostimulants on the growth and biochemical composition of Amaranthus hybridus L. S. Afr. J. Bot. 2019, 124, 1-7. [CrossRef]

21. Thakur, M.; Sohal, B.S. Role of Elicitors in Inducing Resistance in Plants against Pathogen Infection: A Review. ISRN Biochem. Artic. 2013, 1-10. [CrossRef] [PubMed]

22. Stockwell, V.O.; Stack, J.P. Using Pseudomonas spp. for Integrated Biological Control. Phytopathology 2007, 97, 244-249. [CrossRef] [PubMed]

23. Navarro, M.O.P.; Simionato, A.S.; Barazetti, A.R.; dos Santos, I.M.O.; Cely, M.V.T.; Chryssafidis, A.L.; Andrade, G. Disease-Induced resistance and plant immunization using microbes. In Plant-Microbe Interactions in Agro-Ecological Perspectives; Singh, D., Singh, H., Prabha, R., Eds.; Springer: Singapore, 2017; pp. 447-465. [CrossRef]

24. Gross, H.; Loper, J.E. Genomics of secondary metabolites production by Pseudomonas spp. Nat. Prod. Rep. 2009, 26, 1408-1446. [CrossRef] [PubMed] 
25. Choudhary, D.K.; Prakash, A.; Johri, B.N. Induced systemic resistance (ISR) in plants: Mechanism of action. Indian J. Microbiol. 2007, 47, 289-297. [CrossRef] [PubMed]

26. Haas, D.; Defágo, G. Biological control of soil-borne pathogens by fluorescent pseudomonads. Nat. Rev. Microb. 2005, 3, 307-319. [CrossRef]

27. Zzanatta, Z.G.C.; Moura, A.B.; Maia, L.C.; Santos, A.S. Bioassay for selection of biocontroller bacteria against bean common blight (Xanthomonas axonopodis pv. phaseoli). Braz. Microbiol. 2007, 38, 511-515. [CrossRef]

28. Leisinger, T.; Margraff, R. Secondary metabolites of fluorescent pseudomonads. Microb. Rev. 1979, 43, 422-442. [CrossRef]

29. Haas, D.; Keel, C.; Laville, J.; Maurhofer, M.; OberhÄnsli, T.; Schinder, U.; Voisard, C.; Wüthrich, B.; Defago, G. Secondary Metabolites of Pseudomonas Fluorescens Strain CHA0 Involved in the Suppression of Root Diseases. In Advances in Molecular Genetics of Plant-Microbe Interactions, Vol. 1. Current Plant Science and Biotechnology in Agriculture; Hennecke, H., Verma, D.P.S., Eds.; Springer: Dordrecht, The Netherland, 1991; Volume 10, pp. 450-456. [CrossRef]

30. Neidig, N.; Rüdiger, J.P.; Scheu, S.; Jousset, A. Secondary Metabolites of Pseudomonas fluorescens CHA0 Drive Complex Non-Trophic Interactions with Bacterivorous Nematodes. Microb. Ecol. 2011, 61, 853-859. [CrossRef]

31. Jankiewicz, U.; Koltonowicz, M. The Involvement of Pseudomonas Bacteria in Induced Systemic Resistance in Plants (Review). Appl. Biochem. Microbiol. 2012, 48, 244-249. [CrossRef]

32. Domenech, J.; Ramos, B.; Probanza, A.; Lucas, J.A.; Gutierrez, F.J. Elicitation of systemic resistance and growth promotion of Arabidopsis thaliana by PGPRs from Nicotiana glauca: A study of the putative induction pathway. Plant Soil. 2007, 290, 43-50. [CrossRef]

33. Ramos-Solano, B.; Lucas Garcia, J.A.; Garcia-Villaraco, A.; Algar, E.; Garcia-Cristobal, J.; Gutierrez Manero, F.J. Siderophore and chitinase producing isolates from the rhizosphere of Nicotiana glauca Graham enhance growth and induce systemic resistance in Solanum lycopersicum L. Plant Soil. 2010, 334, 189-197. [CrossRef]

34. Gutiérrez Mañero, F.J.; Algar, E.; Martín Gómez, M.S.; Saco Sierra, M.D.; Ramos-Solano, B. Elicitation of secondary metabolism in Hypericum perforatum by rhizosphere bacteria and derived elicitors in seedlings and shoot cultures. Pharm. Biol. 2012, 50, 10. [CrossRef]

35. Bonilla, A.; Sarria, A.L.; Algar, E.; Ledesma, F.J.; Ramos-Solano, B.; Fernandes, J.B.; Gutierrez-Mañero, F.J. Microbe associated molecular patterns from rhizosphere bacteria trigger germination and Papaver somniferum metabolism under greenhouse conditions. Plant Physiol. Biochem. 2014, 74, 133-140. [CrossRef] [PubMed]

36. Ramos-Solano, B.; Garcia-Villaraco, A.; Gutierrez-Manero, F.J.; Lucas, J.A.; Bonilla, A.; Garcia-Seco, D. Annual changes in bioactive contents and production in field-grown blackberry after inoculation with Pseudomonas fluorescens. Plant Physiol. Biochem. 2014, 74,1-8. [CrossRef]

37. Garcia-Seco, D.; Zhang, Y.; Gutierrez-Manero, F.J.; Martin, C.; Ramos-Solano, B. Application of Pseudomonas fluorescens to blackberry under field conditions improves fruit quality by modifying flavonoid metabolism. PLoS ONE 2015, 10, e0142639. [CrossRef]

38. Martin-Rivilla, H.; Garcia-Villaraco, A.; Ramos-Solano, B.; Gutierrez-Manero, F.J.; Lucas, J.A. Improving flavonoid metabolism in blackberry leaves and plant fitness by using the bioeffector Pseudomonas fluorescens N 21.4 and its metabolic elicitors: A biotechnological approach for a more sustainable crop. J. Agric. Food Chem. 2020, in press. [CrossRef]

39. Martin-Rivilla, H.; Garcia-Villaraco, A.; Ramos-Solano, B.; Gutierrez-Manero, F.J.; Lucas, J.A. Metabolic elicitors of Pseudomonas fluorescens N 21.4 elicit flavonoid metabolism in blackberry fruit. J. Sci. Food Agric. 2020, in press. [CrossRef]

40. Sumayo, M.; Hahm, M.S.; Ghim, S.Y. Determinants of Plant Growth-promoting Ochrobactrum lupini KUDC1013 Involved in Induction of Systemic Resistance against Pectobacterium carotovorum subsp. carotovorum in Tobacco Leaves. Plant Pathol. J. 2013, 29, 174-181. [CrossRef]

41. Wang, C.C.; Prasaina, J.K.; Barnesa, S. Review of the methods used in the determination of phytoestrogens. J. Chromatogr. B 2002, 777, 3-28. [CrossRef]

42. Lozovaya, V.V.; Lygin, A.V.; Zernova, O.V.; Li, S.; Hartman, G.L.; Widholm, J.M. Isoflavonoid accumulation in soybean hairy roots upon treatment with Fusarium solani. Plant Physiol. Biochem. 2004, 42, 671-679. [CrossRef] 
43. Remans, T.; Smeets, K.; Opdenakker, K.; Mathijsen, D.; Vangronsveld, J.; Cuypers, A. Normalisation of real-time RT-PCR gene expression measurements in Arabidopsis thaliana exposed to increased metal concentrations. Planta 2008, 227, 1343-1349. [CrossRef] [PubMed]

44. Hillwig, M.L.; Zhu, Q.; Liu, X. Biosynthesis of ambiguine indole alkaloids in cyanobacterium Fischerella ambigua. ACS Chem. Biol. 2013, 9, 372-377. [CrossRef] [PubMed]

45. Siebers, M.; Brands, M.; Wewer, V.; Duan, Y.; Holzl, G.; Dormann, P. Lipids in plant-microbe interactions. Biochim. Biophys. Acta 2016, 1861, 1379-1395. [CrossRef] [PubMed]

46. Lenarcic, T.; Albert, I.; Bohm, H.; Hodnik, V.; Pirc, K.; Zavec, A.B.; Podobnik, M.; Pahovnik, D.; Zagar, E.; Pruitt, R.; et al. Eudicot plant-specific sphingolipids determine host selectivity of microbial NLP cytolysins. Science 2017, 358, 1431-1434. [CrossRef] [PubMed]

47. Ali, U.; Li, H.; Wuang, X.; Guo, L. Emerging Roles of Sphingolipid Signaling in Plant Response to Biotic and Abiotic Stresses. Mol. Plant 2018, 11, 1328-1343. [CrossRef]

48. Sokal, R.R.; Rohlf, F.J. Introducción a la bioestadística; Editorial Reverte SA: Barcelona, Spain, 1980.

49. Yin, X.; Feng, T.; Liu, J.K. Structures and cytotoxicities of three new sesquiterpenes from cultures of Armillaria sp. Nat. Prod. Bioprospect 2012, 2, 245. [CrossRef]

50. Jing, W.; Zhang, X.X.; Zhou, H.; Wang, Y.; Yang, M.; Long, L.; Gao, H. Naturally occurring cassane diterpenoids (CAs) of Caesalpinia: A systematic review of its biosynthesis, chemistry and pharmacology. Fitoterapia 2019, 134, 226-249. [CrossRef]

51. Lopes, L.P.; Oliveira, J.G., Jr.; Beranger, J.P.O.; Góis, C.G.; Vasconcellos, F.C.S.; San Martin, J.A.B.; Andrade, C.G.T.J.; Mello, J.C.P.; Andrade, G. Activity of extracellular compounds of Pseudomonas sp. against Xanthomonas axonopodis in vitro and bacterial leaf blight in eucaliptus. Trop. Plant Pathol. 2012, 37, 4. [CrossRef]

52. Liu, L.; Sonbol, F.M.; Huot, B.; Gu, Y.; Withers, J.; Mwimba, M.; Yao, J.; He, S.Y.; Dong, X. Salicylic acid receptors activate jasmonic acid signalling through a non-canonical pathway to promote effector-triggered immunity. Nat. Commun. 2016, 7, 13099. [CrossRef]

53. Betsuyaku, S.; Katou, S.; Takebayashi, Y.; Sakakibara, H.; Fukuda, H. Salicylic Acid and Jasmonic Acid Pathways are Activated in Spatially Different Domains Around the Infection Site During Effector-Triggered Immunity in Arabidopsis thaliana. Plant Cell Physiol. 2017, 59, 8-16. [CrossRef]

54. Caarls, L.; Pieterse, C.M.J.; Van Wees, S.C.M. How salicylic acid takes transcriptional control over jasmonic acid signaling. Front Plant Sci. 2015, 6, 1-11. [CrossRef] [PubMed]

55. Becher, P.G.; Keller, S.; Jung, G.; Roderich, D.S.; Juttner, F. Insecticidal activity of 12-epi-hapalindole J isonitrile. Phytochemistry 2007, 68, 2493-2497. [CrossRef] [PubMed]

56. Smitka, T.A.; Bonjouklian, R.; Doolin, L.; Jones, N.D.; Deeter, J.B.; Yoshida, W.Y.; Prinsep, M.R.; Moore, R.E.; Patterson, G.M.L. Ambiguine isonitriles, fungicidal hapalindole-type alkaloids from three genera of blue-green algae belonging to the Stigonemataceae. J. Organ. Chem. 1992, 57, 857-861. [CrossRef]

57. Mo, S.Y.; Krunic, A.; Chlipala, G.; Orjala, J. Antimicrobial ambiguine isonitriles from the cyanobacterium Fischerella ambigua. J. Nat. Prod. 2009, 72, 894-899. [CrossRef] [PubMed]

58. Mo, S.Y.; Krunic, A.; Santarsiero, B.D.; Franzblau, S.G.; Orjala, J. Hapalindole-related alkaloids from the cultured cyanobacterium Fischerella ambigua. Phytochemistry 2010, 71, 2116-2123. [CrossRef] [PubMed]

59. Lozano, G.L.; Park, H.B.; Bravo, J.I.; Armstrong, E.A.; Denu, J.M.; Stabb, E.V.; Broderick, N.A.; Crawford, J.M.; Handelsman, J. Bacterial Analogs of Plant Tetrahydropyridine Alkaloids Mediate Microbial Interactions in a Rhizosphere Model System. Appl. Environ. Microb. 2019, 85, e03058-18. [CrossRef] [PubMed]

60. Heaver, S.L.; Johnson, L.E.; Ley, R.E. Sphingolipids in host-microbial interactions. Curr. Opin. Microbiol. 2018, 43, 92-99. [CrossRef]

61. Giorni, P.; Dall'Asta, C.; Reverberi, M.; Scala, V.; Ludovici, M.; Cirlini, M.; Galaverna, G.; Fanelli, C.; Battilani, P. Open Field Study of Some Zea mays Hybrids, Lipid Compounds and Fumonisins Accumulation. Toxins 2015, 7, 3657-3670. [CrossRef]

62. Dall'Asta, C.; Giorni, P.; Cirlini, M.; Gregori, R.; Ludovici, M.; Camera, E.; Fanelli, C.; Battilani, P.; Scala, V. Maize lipids play a pivotal role in the fumonisin accumulation. World Mycotoxin J. 2015, 8, 87-97. [CrossRef]

63. Vorholt, J.A. Microbial life in the phyllosphere. Nat. Rev. Microbiol. 2012, 10, 828-840. [CrossRef]

64. Saïdana, D.; Mahjoub, M.A.; Boussaada, O.; Chriaa, J.; Chéraif, I.; Daami, M.; Mighri, Z.; Helal, N. Chemical composition and antimicrobial activity of volatile compounds of Tamarix boveana (Tamaricaceae). Microbiol. Res. 2006, 163, 445-455. [CrossRef] [PubMed] 
65. Selim, S.A.; Aziz, M.H.A.; Mashait, M.S.; Warrad, M.F. Antibacterial activities, chemical constitutes and acute toxicity of Egyptian Origanum majorana L.; Peganum harmala L. and Salvia officinalis L. essential oils. Afr. J. Pharm. Pharm. 2013, 7, 725-735. [CrossRef]

66. Choudhary, N.; Singh, V. Piper longum Linn: A review of its phytochemicals and their network pharmacological evaluation. PLoS ONE 2018, 13, e0191006. [CrossRef]

67. Kiran, G.S.; Sabarathnam, B.; Selvin, J. Biofilm disruption potential of a glycolipid biosurfactant from marine Brevibacterium casei. Femns Immunol. Med. Microbiol. 2010, 59, 432-438. [CrossRef]

68. Al-Jassaci, M.; Mohammed, G.; Hameed, I. Secondary metabolites analysis of Saccharomyces cerievisiae and evaluation of antibacterial activity. Int. J. Pharm. Clin. Res 2016, 8, 304-315.

69. Anderson, R. Alkylamines: Novel lipid constituents in Deinococcus radiodurans. BBA-Gen Subj. 1983, 753, 266-268. [CrossRef]

70. Nakano, C.; Kudo, F.; Eguchi, T.; Ohnishi, Y. Genome mining reveals two novel bacterial sesquiterpene cyclases: (-)-germacradien-4-ol and (-)-epi-alpha-bisabolol synthases from Streptomyces citricolor. Chembiochem 2011, 12, 2271-2275. [CrossRef]

71. Yamada, Y.; Kuzuyama, T.; Komatsu, M.; Shin-Ya, K.; Omura, S.; Cane, D.E.; Ikeda, H. Terpene synthases are widely distributed in bacteria. Proc. Natl. Acad. Sci. USA 2014, 112, 857-862. [CrossRef]

72. Fraga, B.M. Natural sesquiterpenoids. Nat. Prod. Rep. 2013, 30, 1226-1264. [CrossRef]

73. Bohnert, M.; Nutzmann, H.W.; Schroeckh, V.; Horn, F.; Dahse, H.M.; Brakhage, A.A.; Hoffmeister, D. Cytotoxic and antifungal activities of melleolide antibiotics follow dissimilar structure-activity relationships. Phytochemistry 2014, 105, 101-108. [CrossRef]

74. Helfrich, E.J.N.; Lin, G.M.; Voigt, C.A.; Clardy, J. Bacterial terpene biosynthesis: Challenges and opportunities for pathway engineering. Beilstein J. Organ. Chem. 2019, 15, 2889-2906. [CrossRef] [PubMed]

75. Blin, K.; Pascal Andreu, V.; de los Santos, E.L.C.; Del Carratore, F.; Lee, S.Y.; Medema, M.H.; Weber, T. The antiSMASH database version 2: A comprehensive resource on secondary metabolite biosynthetic gene clusters. Nucleic Acids Res. 2019, 47, D625-D630. [CrossRef] [PubMed]

76. Medema, M.H.; Kottmann, R.; Yilmaz, P.; Cummings, M.; Biggins, J.B.; Blin, K.; de Bruijn, I.; Chooi, Y.H.; Claesen, J.; Coates, R.C.; et al. Minimum Information about a Biosynthetic Gene cluster. Nat. Chem. Biol. 2015, 11, 625-631. [CrossRef] [PubMed]

77. Kanda, N.; Ishizaki, N.; Inoue, M.; Oshima, A.; Handa, T.; Kitahara, J. Antibiotic. DB 23-73, a new alkylresorcinol antibiotic. J. Antibiot. Res. 1975, 28, 935-942. [CrossRef] [PubMed]

78. Budzikiewicz, H.; Scholl, W.; Neuenhaus, G.; Pulverer, H.; Korth, Z.; Naturforsch, C. Dialkyl Resorcinols from Pseudomonas aureofaciens. Z. Naturforsch. 1980, 35, 909-910. [CrossRef] 